\title{
Myanmar: Staff-Monitored Program
}

This document was prepared by a staff team of the International Monetary Fund following discussions that ended on November 21, 2012, with officials of Myanmar on economic developments and policies. The views expressed in this document are those of the staff team and do not necessarily reflect the views of the government of Myanmar or the Executive Board of the IMF.

The policy of publication of staff reports and other documents by the IMF allows for the deletion of market-sensitive information.

\author{
Copies of this report are available to the public from \\ International Monetary Fund • Publication Services \\ $70019^{\text {th }}$ Street, N.W. • Washington, D.C. 20431 \\ Telephone: (202) 623-7430 • Telefax: (202) 623-7201 \\ E-mail: publications@imf.org Internet: http://www.imf.org
}

\section{International Monetary Fund Washington, D.C.}




\section{INTERNATIONAL MONETARY FUND}

\section{MYANMAR}

\section{STAFF-MONITORED PROGRAM}

January 2, 2013

\section{EXECUTIVE SUMMARY}

Context. The international community has suspended most sanctions against Myanmar following the April by-elections and broader political reconciliation. Reform momentum is strong, with several important steps already taken over the last year and many more planned. Nevertheless, Myanmar's transition to an open market economy will take time and there are risks to reform implementation.

Past Fund advice. The main recommendations-including during the last Article IV consultation-were to reform the exchange rate system; grant the Central Bank of Myanmar (CBM) autonomy to pursue price stability and decrease deficit monetization; and improve public financial management (PFM), while reorienting spending toward social sectors. To foster inclusive growth, financial development and structural reforms to raise agricultural productivity, enhance the business climate, and remove barriers to trade and foreign investment were emphasized. The authorities undertook a number of reforms in line with this advice, in particular in modernizing the exchange rate system.

Staff-Monitored Program (SMP). In the attached Letter of Intent, dated December 28, 2012, the authorities request an SMP covering the period through December 2013. The SMP would help monitor their economic reforms and policies, and facilitate arrears clearance with official creditors. The government's medium-term vision is to achieve sustainable and equitable growth, reintegrate Myanmar with the global economy, and reduce poverty. During this transition process, their immediate priorities are ensuring macroeconomic stability and strengthening tools for macroeconomic management. The 12-month SMP supports these objectives. It takes into account capacity constraints in policy making and implementation, complements planned engagement by the World Bank and Asian Development Bank (AsDB) in structural areas, and will be supported by continuing technical assistance.

Exchange rate arrangement. Myanmar continues to avail itself of transitional arrangements under Article XIV, although it has eliminated all Article XIV restrictions. Myanmar maintains exchange restrictions and multiple currency practices (MCPs) subject to Fund approval under Article VIII. The exchange rate regime is classified as other managed arrangement. 


\section{Approved By}

Jerald Schiff and

Dhaneshwar Ghura
Discussions took place in Yangon and Nay Pyi Taw during November 5-21 2012. Staff met with U Win Shein, Union Minister of Finance and Revenue and Central Bank of Myanmar Governor $U$ Than Nyein, other senior officials, parliamentarians, as well as representatives from the private sector, banking industry, and the donor community. The mission comprised Ms. Karasulu (Head), Messrs. Dodzin, Syed (all APD), Kashiwase (FAD), Asonuma and Painchaud (all SPR). Messrs. Schiff and Davies (all APD) also joined the mission. The mission collaborated closely with staff from the AsDB and the World Bank, who were in Myanmar concurrently.

\section{CONTENTS}

BACKGROUND

THE AUTHORITIES' ECONOMIC PROGRAM FOR 2013

A. Exchange Rate Regime

B. Monetary Framework

C. Financial Sector Policies

D. Fiscal Sector

E. Arrears Resolution and Debt Sustainability

F. Structural Policies

PROGRAM MONITORING AND RISKS

STAFF APPRAISAL

BOX

1. Key Recent Economic Reforms

\section{FIGURES}

1. Myanmar and Its Peers: Selected Indicators 5

2. Macroeconomic Developments

\section{TABLES}

1. Selected Economic Indicators, 2007/08-2012/13

2. Summary Operations of the Nonfinancial Public Sector, 2007/08-2017/18

3. Monetary Survey, 2007/08-2012/13 _ 20

4. Balance of Payments, 2007/08-2017/18__ 21

5. Medium-Term Projections, 2007/08-2017/18 _ 22 


\section{APPENDIX}

I. Letter of Intent

\section{ATTACHMENTS}

I. Memorandum of Economic and Financial Policies 25

II. Technical Memorandum of Understanding 


\section{BACKGROUND}

1. Myanmar is emerging from half a century of isolation. In the 1960s, Myanmar faced a bright future as a major rice exporter and one of South-East Asia's leading economies. But it has since fallen far behind, as the rest of the region transformed itself through market-oriented reforms and trade integration. Since 2011, however, the new government has been charting a fresh course centered on domestic political reconciliation, international re-engagement, and economic reforms.

2. Myanmar is a low-income country in Asia (Figure 1). Per capita GDP is around US $\$ 900$ and one-quarter of Myanmar's estimated 60 million people live below the national poverty line. Tools to manage the economy are severely underdeveloped, with poor revenue performance leading to persistent fiscal deficits financed by the central bank. This has contributed to high and volatile inflation, averaging 23 percent between 2001 and 2010, hitting the poor especially hard and undermining domestic confidence in the kyat. Limited financial intermediation has repressed savings and investment. Together with weak government revenues, this has contributed to low levels of human and physical capital, notably in the form of insufficient energy and transport infrastructure. The economy remains vulnerable to shocks, given both its narrow dependence on natural resources and low-productivity agriculture.

\section{With the right reforms, Myanmar has the opportunity to realize its rich economic} potential. Myanmar is a large country, roughly the size of France. Its young labor force, abundant natural resources (including natural gas, copper, timber and gemstones), and proximity to some of the most dynamic economies in the world—notably China, India and the ASEAN-5-are major advantages.

\section{Myanmar can benefit from the experience of countries that have made similar} transitions, including many of its Asian peers. Their experiences emphasize a few key ingredients for sparking inclusive and broad-based growth and poverty reduction. Most fundamental is the need for a stable macroeconomic environment to lay the foundations for long-term growth -notably low and stable inflation, a sustainable fiscal position, independent and effective monetary policy, a unified and market-based exchange rate, and adequate international reserves. In addition, to fund investments in infrastructure and human capital, the government requires adequate resources and the financial sector needs to become more efficient at mobilizing and intermediating savings and to improve access to financial services. Openness to international trade and higher foreign direct investment (FDI) can also play an important role. Attracting such flows and utilizing them well in turn requires improvements to the business climate and greater transparency. Meanwhile, structural reforms to boost agricultural productivity and liberalize trade can help facilitate job creation in higher value-added sectors. 
Figure 1. Myanmar and Its Peers-Selected Indicators

Living standards remain among the lowest in the region.

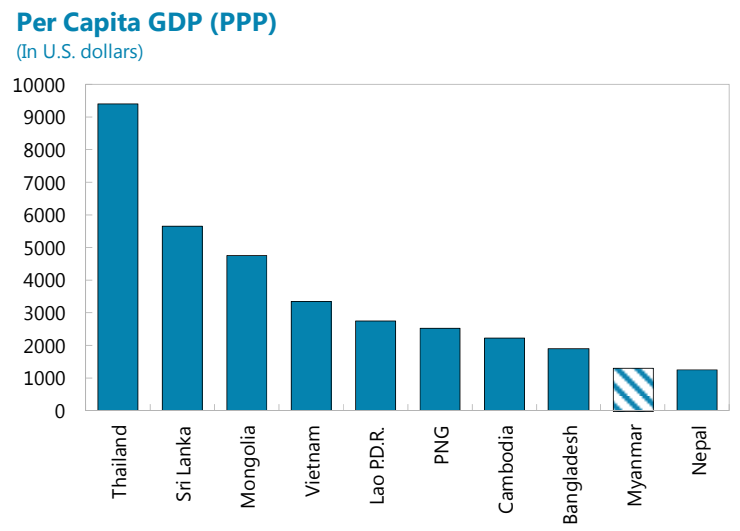

...and monetized in the past. This has been recently reduced...

Public Domestic Spending, Credit to Government, and Inflation

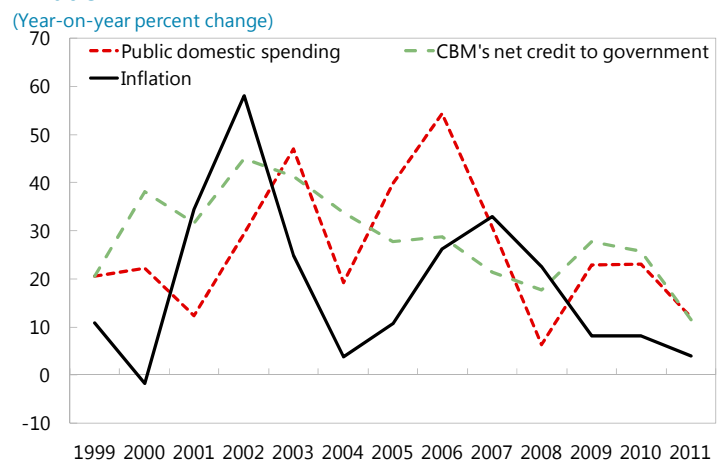

However, low government revenues limit the scope for social expenditures...

Government Revenue Excluding Grants, 2011

(In percent of GDP)

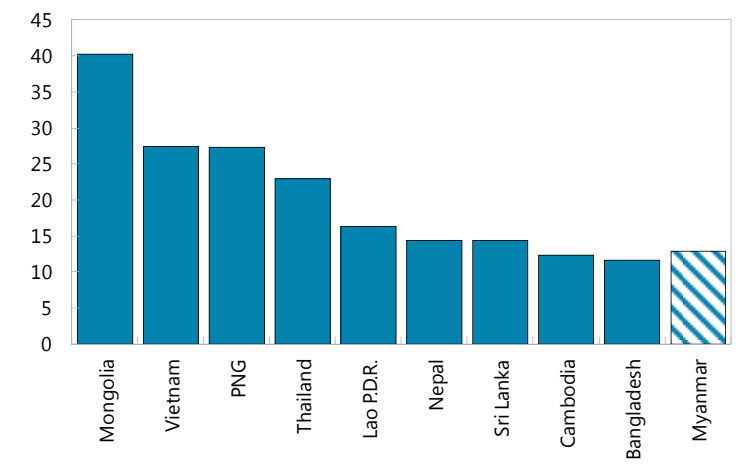

While not excessive, fiscal deficits have been persistent....

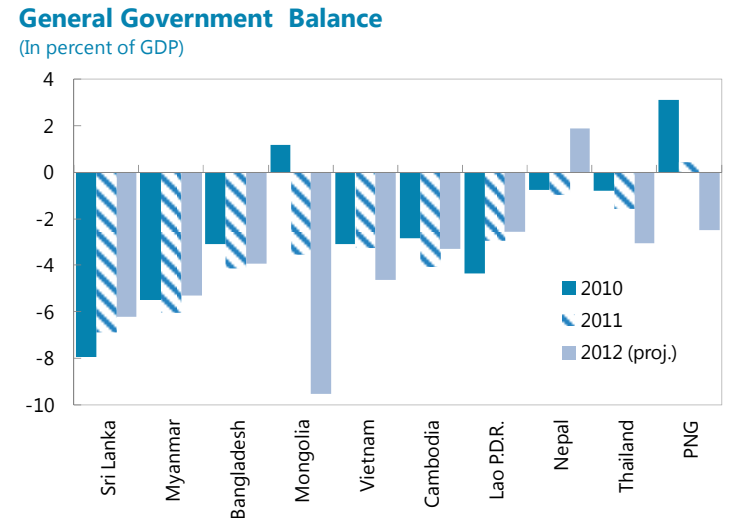

...contributing to much lower inflation.

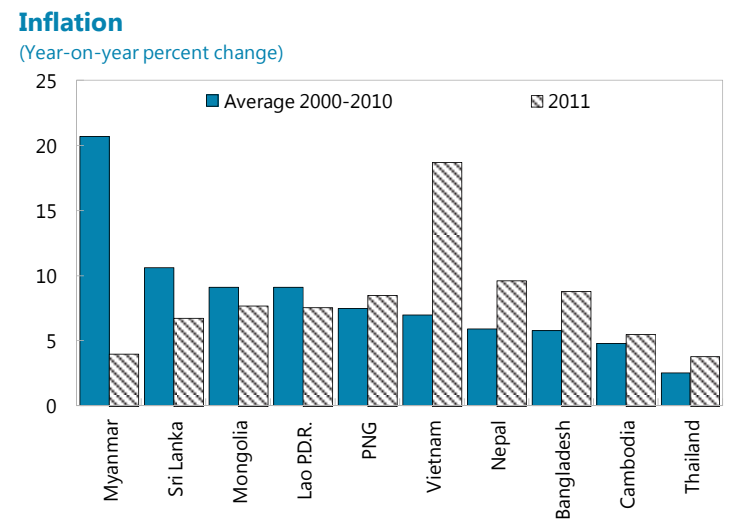

....and financial intermediation has been depressed by administrative controls.

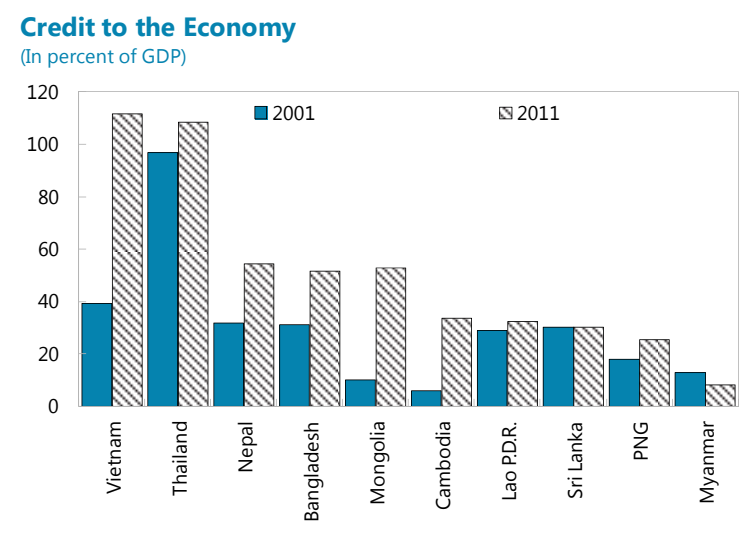

Sources: Authorities; Direction of Trade; IMF's World Economic Outlook; and IMF staff calculations. 


\section{RECENT DEVELOPMENTS AND OUTLOOK}

5. Over the last year, Myanmar has embarked on an ambitious set of reforms (Box 1$)$. The authorities aim to comprehensively modernize the economy and integrate it with the world, and are developing a national economic plan to guide medium-term policies. They have also taken steps to improve their macroeconomic management capacity, especially with regard to exchange rate and monetary policies.

6. Partly as a result, economic performance has improved (Figure 2). In FY 2011/12, ${ }^{1}$ growth accelerated slightly to $5 \frac{1}{2} 2$ percent, bolstered by foreign investment in energy and exports of commodities. Inflation fell to 5 percent $(\mathrm{y} / \mathrm{y})$, about half of that in the previous year, mainly due to declining food prices, supported by reduced central bank financing of the budget deficit. Despite a widening of the current account deficit to $2 \frac{1}{2}$ percent of GDP, FDI inflows, mainly in the energy sector, saw international reserves rise to US $\$ 4.2$ billion at end-September, covering 31/4 months of recorded prospective imports of goods and nonfactor services. ${ }^{2}$ The fiscal deficit rose moderately to 6 percent of GDP, in part due to an increase in pensions and a tax exemption on key agricultural exports to address deteriorating external competitiveness. Credit to the private sector continues to grow rapidly, at 63 percent $y / y$ at end-July, but from a very low base (81/4 percent of GDP). This is mainly due to structural factors such as the licensing of four new banks, expansion of branch networks, broadening of eligible collateral to include key agricultural export goods, and doubling of the loan ceiling to farmers.

7. The short-term outlook is favorable. Notwithstanding the difficult external environment, Myanmar's economic prospects have improved, reflecting reform momentum and favorable business sentiment following the suspension of sanctions. In FY2012/13, growth is projected to accelerate to $6 \frac{1}{4}$ percent on the back of rising investment. Inflation is expected to pick up to around 6 percent, mostly due to bottoming out of the food prices after moderation in the previous year. ${ }^{3}$ The budget deficit is projected to decline to about $5 \frac{1}{4}$ percent of GDP, with increased spending on health, education and infrastructure, afforded by higher net revenues from state economic enterprises (SEEs) as a result of adopting a more realistic market-based exchange rate in their operations.

\footnotetext{
${ }^{1}$ The fiscal year runs from April 1 to March 31.

${ }^{2}$ International reserves comprise those held by the CBM, as well as deposits held abroad by state banks (excluding those that belong to private domestic entities). Before the breakdown in ownership (state vs. private) was known, all deposits held abroad by state banks were reported as international reserves; historical figures in Tables 1, 4 and 5 have been adjusted retroactively to provide estimates of reserves excluding those held on behalf of private entities.

${ }^{3}$ Food items comprise more than 68 percent of the official CPI index.
} 


\section{Box 1. Myanmar: Key Recent Economic Reforms}

Since the elections in November 2010, the authorities have undertaken several important reforms, particularly with regard to exchange rate and monetary policies.

An overvalued peg has been replaced by a managed float, and steps are being taken to unify the remaining exchange rates. On April 1, 2012, with IMF technical assistance, the peg to the SDR at $8.51 \mathrm{kyat} / \mathrm{SDR}$ was replaced by a managed float. The reference exchange rate is now determined by an auction mechanism. A new foreign exchange management law has also been passed, targeting to lift all restrictions on current payments and transfers abroad. Its full implementation awaits the drafting of the necessary regulations. Nonetheless, some key exchange restrictions on current international payments and transfers have already been lifted, notably the requirement to use only export proceeds for imports. In addition, a number of private banks have been issued licenses to conduct international banking. As a consequence, the reference and informal market rates have moved broadly together.

A central bank law has been approved by the cabinet and awaits passage by Parliament. It aims to provide more operational autonomy to the CBM, as well as to arm it with core central banking functions currently undertaken by state banks, although there is scope for further improvements. Meanwhile, official reserves held at state banks have been identified and their gradual transfer to the CBM has begun. The CBM has also begun acquiring more international reserves through its daily foreign exchange auctions.

Deposit rates have been made more flexible and some administrative curbs on credit extension relaxed. While lending rates remain fixed, deposit rates have been liberalized within a fixed corridor and restrictions on eligible collateral eased. The deposit-to-capital ratio ${ }^{1}$ and additional capital requirements for branch expansion have been lifted. Private banks have been permitted to open foreign currency accounts, and are now installing technical infrastructure for international transactions. To expedite technology transfer, modalities for participation of foreign banks are also being considered.

The FY2012/13 budget was, for the first time, debated in and approved by the parliament. It features significantly higher spending on critical areas such as health and education. As an initial step toward financial autonomy, SEEs have been given responsibility to self-finance part of their costs from their operating revenues rather than through budget allocations. Some changes have also been made to tax policy-the withholding tax on imports has been abolished, a tax on key agricultural products eliminated to support competitiveness, the commercial tax on domestic sales simplified, the tax base broadened by requiring public sector employees to pay income tax, and the progressivity of the income tax increased.

Legislation aimed at strengthening the agricultural sector and the business climate has been adopted. A land reform giving titles to farmers and a new microfinance law to improve access to finance were passed by the parliament to support agricultural development. A new law aimed at ensuring a stable and predictable environment for foreign investment has also been passed recently, and an overhaul of the law on Special Economic Zones-a key element of the government's development plan to support industrialization—is being drafted.

${ }^{1}$ The deposit-to-capital ratio limited deposit taking by private banks to 10 times of paid-up capital and discouraged deposit growth. 
Figure 2. Myanmar-Macroeconomic Developments

Growth is expected to pick up, driven by improved business confidence and reform momentum.

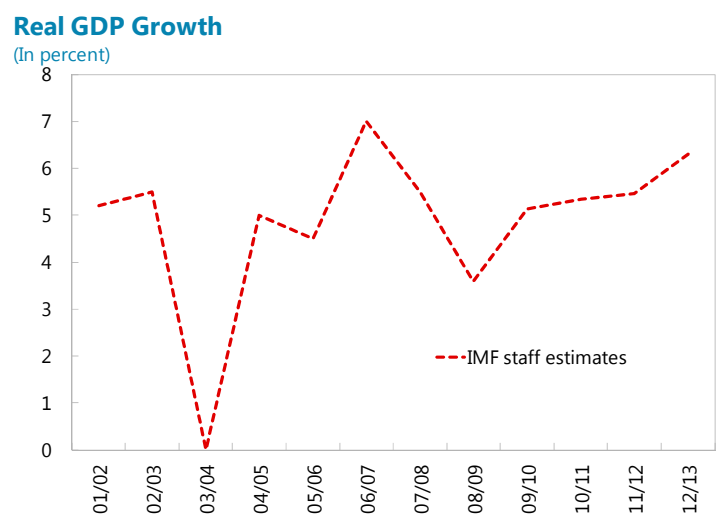

...helped by the interest rate adjustment in late 2011 that now provides banks a margin on their treasury bond holdings.

Interest Rate and Inflation, 2005-12 (Percent)

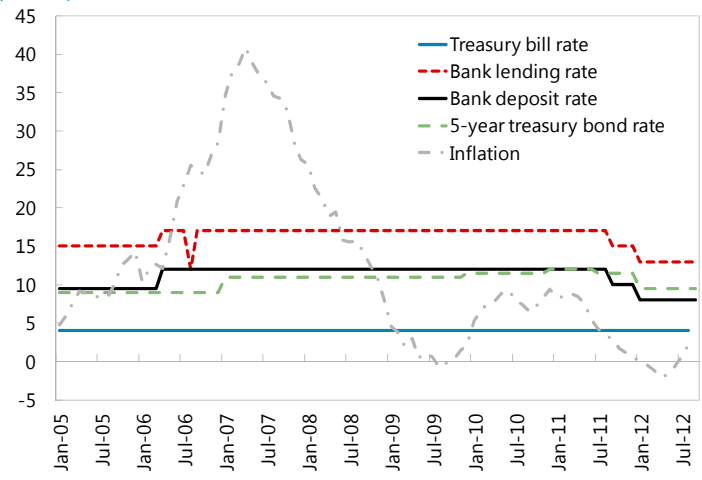

....and informal and formal market rates have moved broadly in line.

Exchange Rates and CBM Intervention (Kyats/U.S. dollar)

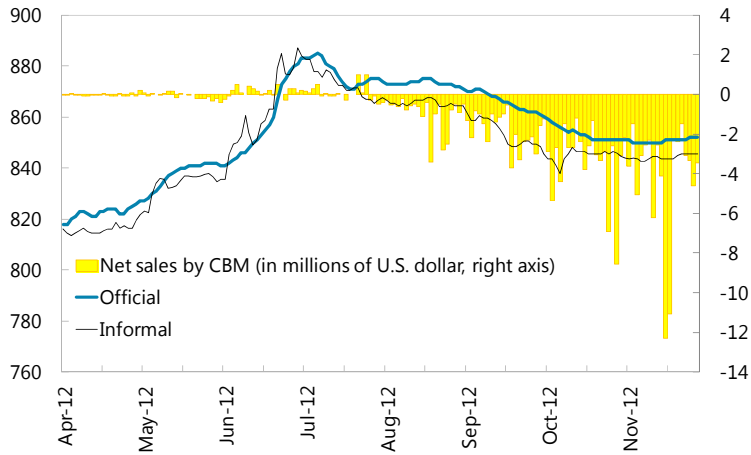

Food prices started to pick up after moderation and the central bank financing of the deficit was contained.

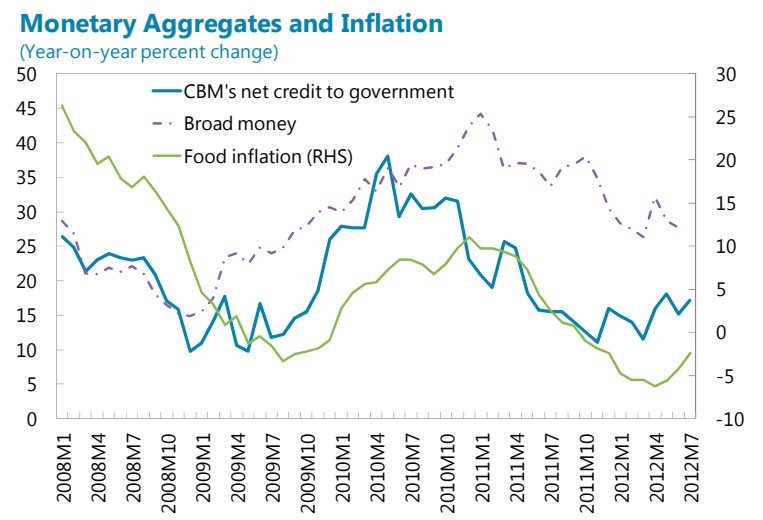

Following the move to a managed float, the fiscal deficit is narrowing modestly, owing to higher resource revenues.

Fiscal Overall Balance and Financing (In percent of GDP)

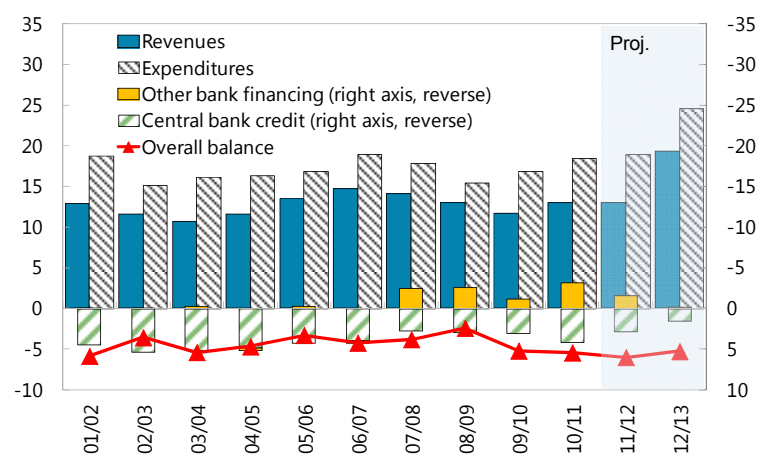

International reserves remain stable due to strong FDI inflows.

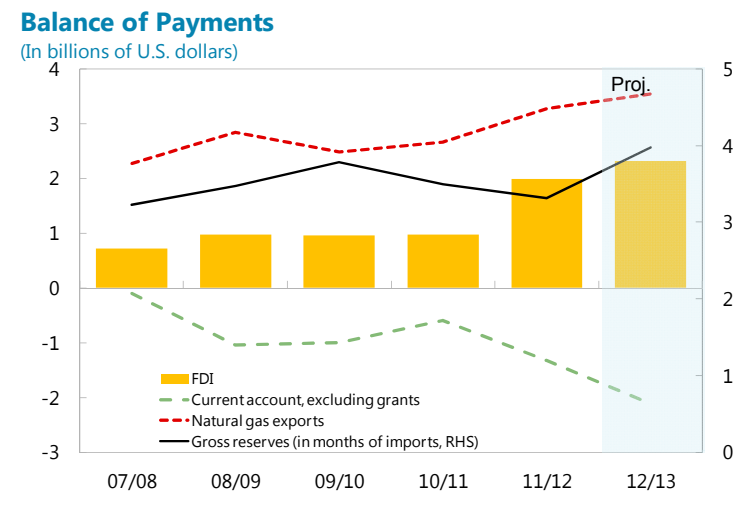

Sources: Authorities; Direction of Trade; IMF's World Economic Outlook; and IMF staff calculations. 
8. External balances remain stable. The market exchange rates (both informal and the auction rate) have remained broadly stable since the move to a managed float. Due to recent import liberalization and the lifting of some exchange restrictions, the current account deficit is expected to widen to 4 percent of GDP in the current fiscal year. Nevertheless, gross international reserves are projected to rise to around 4 months of imports mainly due to robust FDI inflows, primarily into the energy sector.

9. There are several risks to the outlook. On the downside, the main domestic risks arise from limited implementation capacity. Separately, a potential escalation of the ethnic conflict in Rakhine state and other border regions could undermine confidence. Global economic uncertainty also weighs on the outlook. A drop in regional demand would primarily affect agricultural exports and foreign investment inflows, although Myanmar remains mostly insulated from developments in advanced markets. Myanmar's largely agriculture-based economy also remains vulnerable to severe weather events as well as global commodity price shocks. On the upside, a faster response by foreign investors to ongoing reforms could further boost FDI and growth.

10. Medium-term prospects also appear promising. Over the next five years, growth is projected to rise to around 7 percent, provided the reform momentum is maintained. The current account deficit is expected to rise to $5 \frac{1}{2} 2$ percent of GDP, reflecting increased import demand for investment and consumption goods, and financed mainly by higher FDI. Gas exports, forecasted to peak in FY2014/15, should help boost international reserves and government revenue. Spending on health and education is projected to increase, consistent with the authorities' goals. Improved revenue performance, however, should see the medium-term fiscal deficit narrow to around $4 \frac{1}{2}$ percent of GDP, which remains sustainable even under conservative revenue and foreign aid assumptions.

\section{THE AUTHORITIES' ECONOMIC PROGRAM FOR 2013}

11. The authorities' economic goals are outlined in their draft Framework for Economic and Social Reforms. These include raising growth in a sustainable way, opening the economy, reducing poverty, and achieving greater equity. To realize these goals, the government recognizes the need to preserve macroeconomic stability, build a framework and institutions for macroeconomic management, and continue reforms in key economic sectors. The 12-month SMP supports the authorities' economic program in these areas. Its central objectives are threefold: maintaining low and stable inflation within a consistent macroeconomic framework; building international reserve buffers in light of the on-going liberalization of imports and foreign exchange regime; and continuing to build the institutions and instruments needed to ensure macroeconomic stability. 
12. The authorities' reforms supported by the SMP take into account capacity constraints and focus on measures to manage the risks arising from opening up and liberalizing the economy. The authorities are cognizant of the low technical and implementation capacity commensurate of an economy at Myanmar's level of development, and risks from a rushed and uncoordinated approach to economic liberalization. Taking into account these constraints and to mitigate these risks, the program emphasizes a core set of fundamental steps over a one-year period to guide and manage the transition. It places heavy emphasis on moving toward a unified exchange rate and a more independent monetary policy at an early stage. Given the vulnerabilities that may arise from dismantling financial sector controls in a hurried fashion amid a rapidly changing environment, it prioritizes strengthening the supervisory and regulatory framework before further financial liberalization. On the fiscal front, it aims to limit fiscal deficits and begin to take steps to increase tax revenues to allow higher spending on priority areas while limiting central bank financing and reducing dependence on natural resource revenues over time. In all these areas, the authorities' policies will continue to be supported by IMF technical assistance.

13. The reforms will be closely coordinated with other key development partners. The World Bank and AsDB are preparing operations centered on boosting long-term growth by strengthening PFM, improving the investment climate, promoting rural growth and developing human capital. These operations are planned to commence following expected arrears resolution with these institutions and will complement the macroeconomic focus of the SMP. In addition, the World Bank has worked closely with the IMF team in reviewing Myanmar's PFM. World Bank and IMF staff are also collaborating in providing support and policy advice on financial sector reforms, including through joint missions.

\section{A. Exchange Rate Regime}

\section{Completing exchange rate unification is a crucial first step in a series of reforms} needed to establish macroeconomic stability and facilitate the development process. It is also in line with the authorities' objective to join the ASEAN Economic Community. Notwithstanding the elimination of the overvalued official rate, several informal foreign exchange markets exist where multiple exchange rates are determined. Most of these markets are a reflection of the long history of exchange restrictions which encouraged informality. Unifying these would eliminate distortions that negatively affect the economic performance of the country, helping to boost its external competitiveness and business environment. It would also increase transparency and reduce costs, encouraging trade and FDI.

\section{The authorities are continuing to make rapid progress toward accepting their} Article VIII obligations and eliminating MCPs in 2013 (MEFP $\llbracket 7$ and $\llbracket 8$ ). In particular, they are in the process of drafting instructions to remove the remaining exchange restriction on invisibles and ensure a more level playing field for private banks vis-à-vis state banks, with related measures planned to be implemented by March 2013. They have also informally advised banks to refrain from the practice of deviating from the set thresholds around the reference rate in their retail operations. 
These steps would help bring informal flows to the formal market and thus encourage unification of the remaining informal market rates. Finally, the authorities are deliberating on a detailed plan to phase out Foreign Exchange Certificates (FECs), which they plan to announce by March 2013, to eliminate another MCP. ${ }^{4}$

\section{B. Monetary Framework}

16. The recent move to a managed float should be accompanied by a consistent monetary policy framework, focused on achieving low and stable inflation. Traditionally, the CBM has operated without a monetary policy anchor, while monetary policy has been determined by the financing needs of the fiscal deficit. Currently, the CBM is a department within the Ministry of Finance and Revenue (MoFR), with several core central banking functions undertaken by two state banks, Myanma Economic Bank and Myanma Foreign Trade Bank. The CBM relies heavily on direct monetary policy instruments, mainly in the form of reserve requirements and prudential limits on the structure of commercial bank balance sheets. Interest rates have been administratively set for all instruments and maturities, and, until recently, rarely changed. There is no formal interbank market and pervasive controls on banks impede the monetary transmission mechanism.

\section{Greater operational autonomy and assumption of core central banking functions by} the CBM are key (MEFP आ10). The authorities have drafted a law to provide greater autonomy to the CBM, although some aspects_-including ending central bank financing of deficits, and greater clarity on its mandate, regulatory power, and ability to set its own budget-remain to be refined during the parliamentary process in January. The transfer of international reserves currently held by state banks is also proceeding. Going forward, establishing a reserve management function at the CBM and moving the government's foreign exchange treasury functions to the CBM would facilitate continuous accumulation of reserves at the CBM.

\section{The SMP lays the groundwork for adopting a reserve money targeting framework and} improving the monetary instruments for effective monetary control (MEFP \11). Consistent with the heavily cash-based nature of the economy, and its close link with inflation, the CBM should begin monitoring reserve money to guide its monetary operations and interest rate decisions. Implementation will initially rely mainly on deposit and credit auctions, which have recently begun with IMF technical assistance. With some signs of inflation picking up, it will also be important to ensure that the CBM's ability to conduct its monetary operations is not undermined by budgetary constraints. ${ }^{5}$ However, to facilitate a more complete move toward market-based monetary operations, the CBM's monetary tools will need to be gradually improved, the interbank market reopened and the treasury securities market developed.

\footnotetext{
${ }^{4}$ Since 1993, the CBM has issued U.S. dollar FECs that were designed to limit U.S. dollar circulation, but are now also used for certain domestic payments; see IMF Country Report No. 12/104 and Myanmar Selected Issues (March 5, 2012, unpublished).

${ }^{5}$ The fiscal budget does not allocate sufficient resources to the CBM to cover the interest costs of recently introduced deposit and credit auctions.
} 


\section{Financial Sector Policies}

19. Myanmar's financial sector is small, segmented, and repressed due to restrictive administrative controls that limit formal intermediation. These restrictions and incentives to avoid exchange controls have led to a large unregulated and unsupervised shadow financial system, with a significant offshore component. There is only a nascent over-the-counter market for treasury bonds, but at fixed rates. Meanwhile, the regulatory and supervisory treatment of state banks and private banks is uneven, bank governance is poor and banking supervision is far behind international standards.

20. The authorities aim to strengthen the supervisory and regulatory environment and facilitate domestic financing of the budget deficit (MEFP $\llbracket 12$ and 13). Given the risks associated with dismantling controls on the financial sector in an ad hoc way, the IMF and World Bank are working with the government to devise a comprehensive financial sector development master plan for the next few years. In the meantime, the SMP adopts a prudent and gradual approach, focusing on two building blocks: first, improving the regulatory and supervisory framework, notably by instituting a net open foreign exchange position limit and aligning the definition of NPLs and bank capital with international standards; and second, developing treasury markets to provide alternatives to central bank funding of the budget deficit, including the necessary infrastructure to introduce auctions of treasury securities.

\section{Fiscal Sector}

21. Spending needs to be reallocated toward reducing poverty and improving infrastructure, and a foundation laid for higher tax revenues to sustain development spending over the medium term. Although fiscal deficits have not been excessive in recent years, weaknesses in tax policy and administration as well as PFM lead to abnormally low tax revenues, heavy reliance on resource revenues and routine deficit financing by the central bank. The development needs of the country will require a strategy to gradually increase tax revenues over the next several years. To better monitor fiscal goals and support phasing out deficit monetization, improving PFM will be key, including by building treasury and debt management functions in the MoFR, consistent with recent IMF and World Bank advice (MEFP \15). Broader reforms to improve spending efficiency will be informed by a public expenditure review being conducted by the authorities with the help of the Word Bank.

22. The authorities target a budget deficit of around 51/4 percent of GDP in FY2012/13, $3 / 4$ percentage points lower than the last fiscal year. They also increased spending on education and health (including related investment) to about $133 / 4$ percent of total expenditures-or about 31/3 percent of GDP_still low compared to peers. Budget preparations for FY 2013/14 are under way; the authorities plan to target a broadly unchanged fiscal deficit.

\section{The authorities aim to step up tax policy and administration reforms over time}

(MEFP आ16). While this process will take some time the authorities are committed to begin with the modernization of tax administration, centered on the setting up of a large taxpayer office. Going 
forward, additional efforts would be needed to broaden the tax base, primarily by simplifying the commercial and income tax rates. The authorities intend to start this process with taxation of certain special items like alcohol and polluting goods and streamlining tax incentives for investment purposes. Looking ahead, more comprehensive plans for tax policy and revenue administration need to be developed, including consideration of a potential value-added tax.

\section{E. Arrears Resolution and Debt Sustainability}

24. Discussions on clearing Myanmar's arrears are progressing. In April 2012, Myanmar agreed with Japan, its largest creditor, on a plan to resolve its arrears through cancellation of principal payments and overdue charges, as well as rescheduling with the use of bridge loans. Myanmar is also planning to clear its arrears to the AsDB and World Bank in early-2013 with the help of bridge financing from Japan. Meanwhile, the Paris Club has invited the authorities for discussions on arrears resolution in late-January. The authorities recognize that a successful arrears resolution is essential for Myanmar to re-engage with the international community and ensure debt sustainability. They aim to normalize relations with all creditors, supported by the

\begin{tabular}{|c|c|c|c|}
\hline \multicolumn{4}{|c|}{$\begin{array}{l}\text { Myanmar: Projected Stock of External Public and Publicl } \\
\qquad \begin{array}{c}\text { Debt at end of December } 2012 ~ 1 / \\
\text { (Millions of USD) }\end{array}\end{array}$} \\
\hline & Arrears & $\begin{array}{l}\text { Outstanding } \\
\text { Debt }\end{array}$ & $\begin{array}{l}\text { Total } \\
\text { Debt }\end{array}$ \\
\hline Total & 11,004 & 4,341 & 15,345 \\
\hline Multilateral creditors & 953 & 717 & 1,670 \\
\hline \multirow{3}{*}{$\begin{array}{l}\text { World Bank } \\
\text { Asian Development Bank } \\
\text { OPEC }\end{array}$} & 436 & 490 & 926 \\
\hline & 517 & 202 & 719 \\
\hline & 0 & 25 & 25 \\
\hline Bilateral & 10,051 & 3,524 & 13,575 \\
\hline Paris Club & 10,051 & 364 & 10,415 \\
\hline Japan & 6,581 & 79 & 6,661 \\
\hline Other & 3,470 & 285 & 3,754 \\
\hline Non-Paris Club & 0 & 3,160 & 3,160 \\
\hline Commercial & 0 & 100 & 100 \\
\hline $\begin{array}{l}\text { 1/ Source: Paris Club, World Bank } \\
\text { IMF Staff estimates. Data from th } \\
\text { from the Myanmar authorities. }\end{array}$ & $\begin{array}{l}\text { lubelopr } \\
\text { lub has }\end{array}$ & $\begin{array}{l}\text { ank, Myanmar } \\
\text { en fully reconc }\end{array}$ & $\begin{array}{l}\text { rities and } \\
\text { ith the data }\end{array}$ \\
\hline
\end{tabular}
program.

\section{Staff's debt sustainability analysis suggests that Myanmar is classified in debt distress} due to the presence of arrears. However, the planned resolution of arrears to the World Bank, AsDB and Japan would reduce arrears by more than half. Resolution of all arrears on concessional terms and a gradual reduction in reliance on nonconcessional borrowing as assumed under the baseline, would change the rating to low risk of debt distress. The standard stress tests do not reveal significant vulnerabilities for external debt under the baseline although risks to public debt sustainability could emerge in the event of a permanently higher primary fiscal deficit, permanently lower growth over the medium to long term, or a large depreciation of the exchange rate.

\section{As Myanmar opens up, containing external borrowing will be critical to maintaining} macroeconomic stability (MEFP I14). To ensure low risk of debt distress, it will be important to limit nonconcessional external borrowing only to finance economically viable projects in priority sectors such as energy and infrastructure, and at prudent overall levels. For 2013 this implies a ceiling of $\$ 2$ billion on contractual basis. The authorities also aim to keep the fiscal deficit broadly unchanged at about 5 percent of GDP over the medium term to limit the use of nonconcessional borrowing. 


\section{F. Structural Policies}

27. Private sector development is a cornerstone of the government's growth strategy. The authorities consider special economic zones as a focal point to attract FDI to address infrastructure bottlenecks and focus on labor-intensive export industries. This private sector-led strategy will be encouraged through the new FDI law, the planned overhaul of the Special Economic Zones law, and by reducing restrictive administrative controls on domestic firms. A comprehensive investment climate assessment is planned by the World Bank to guide broader reforms.

28. Raising agricultural productivity is also paramount to reduce rural poverty. It is being pursued through the recent land reform which aims to grant titles to farmers, improvements in access to finance, and the building up of rural infrastructure. Beyond increased spending, broader education and health reforms are also planned to improve human capital.

29. The SMP will support these objectives, which are among the focal areas of planned engagement by the World Bank and AsDB (MEFP ฯ18).

\section{PROGRAM MONITORING AND RISKS}

30. The SMP will cover the period through December 2013, and be monitored through semi-annual reviews using quantitative and structural benchmarks (MEFP $\llbracket 20$ and MEFP Tables 1 and 2). Quantitative benchmarks have been set for end-March 2013 and end-September 2013. Two semi-annual reviews will focus on the maintenance of macroeconomic stability, guided by the quantitative benchmarks, and on progress with the reform program, including with reference to the structural benchmarks. The next Article IV consultation will be conducted jointly with the first review. ${ }^{6}$ Consistent with SMP policies, the program is designed to help establish a track record toward a potential upper credit tranche arrangement.

31. Main risks to the program arise from capacity weaknesses that could lead to slippages in implementation and statistical limitations that may complicate timely assessment. Accordingly, the proposed benchmarks have been tailored to the authorities' ownership and implementation capacity. While the authorities have included improving data quality in their new national economic plan, considerable statistical weaknesses exacerbate risks and could affect timely monitoring of quantitative benchmarks. Myanmar does not participate in the IMF's General Data Dissemination System, and no data ROSC is available. In particular, national accounts statistics are only available on an annual basis and have limited coverage; price statistics only cover urban areas and missing prices are not imputed; comprehensive fiscal data are only available on a yearly basis and with considerable lag, while recording of debt statistics is not comprehensive; accounting for international reserves is not straightforward, since some are held in state banks; and coverage and reliability of balance of payments data need to be improved.

\footnotetext{
${ }^{6}$ The last Article IV consultation was concluded on March 19, 2012.
} 
32. The authorities are undertaking efforts to address capacity constraints and data shortcomings, with the help of technical assistance. The IMF has already conducted diagnostic missions in the areas of PFM, tax policy and tax administration, and on government finance statistics in 2012. In addition, technical assistance in the areas of foreign exchange regime, monetary policy instruments, and central bank law has been provided. Technical assistance missions on consumer price and balance of payments statistics are planned for early 2013.

\section{STAFF APPRAISAL}

33. The government has embarked on a bold and historic set of reforms. The exchange rate regime has been changed from a peg to a managed float, and most exchange restrictions have been lifted. The financial sector is being gradually modernized, starting with partial deposit rate liberalization and relaxing of some restrictions on private banks. This year's fiscal budget was debated in the parliament for the first time, and increased spending on critical areas such as health, education, and infrastructure. Laws to support the development goals of the government have been passed, including on land reforms, microfinance, and foreign investment. Discussions on clearing Myanmar's external arrears are also progressing.

34. Reforms are already bearing fruit. Growth is expected to accelerate to $6 \frac{1 / 4}{4}$ percent in FY2012/13 and inflation should remain moderate at around 6 percent next year. Meanwhile, the exchange rate has been stable in recent months, and international reserves have increased. With commitment to strong reforms, Myanmar has the potential to vastly improve the living standards of its people.

35. Nevertheless, the authorities recognize there is still a long way to go. Myanmar remains one of the poorest countries in Asia, with economic development stymied by many distortions. On the macroeconomic front, the government's overarching priorities are twofold: to maintain stability during the transition process, and to build modern tools and institutions for managing a rapidly changing economy. Meeting these will hinge on implementing a core set of policies and reforms. By demonstrating commitment to reform and sound economic management, this would also facilitate a successful resolution of arrears, which is crucial for Myanmar to re-engage with the global community and ensure debt sustainability.

36. Staff support the SMP as a strong initial step to ensuring macroeconomic stability during the reform process. The reform path will need to be carefully planned, sequenced and monitored, especially in light of Myanmar's limited capacity. The 12-month SMP has accordingly been designed to focus on a few key and appropriately ambitious reforms, drawn from the government's own economic plans.

37. First, exchange rate unification will be an important foundational step for securing macroeconomic stability, while at the same time boosting competitiveness and trade.

Achieving it requires bringing more flows from the informal to the formal market, including by 
removing remaining exchange restrictions and ensuring a level playing field for private banks. A strategy for phasing out FECs will be an important milestone in this regard.

38. Second, the recent move to a managed float needs to be accompanied by a consistent monetary policy framework, focused on achieving low and stable inflation. In this context, the

immediate tasks include enabling the CBM to assume core central banking functions and improving its capacity for monetary management. Taking further measures to develop financial markets, while containing risks, and facilitating domestic financing of the budget deficit would also help.

39. Third, fiscal deficits will need to be contained and the stage set for higher and stable revenues to fund Myanmar's considerable development needs. This will take some time, but steps can be gradually initiated to strengthen revenue administration, improve PFM, limit nonconcessional external borrowing, broaden the tax base, simplify tax rates, and develop government securities markets.

40. To mitigate risks from capacity and statistical weaknesses, underlying policies have been tailored to the authorities' implementation abilities. The IMF will also support the authorities' efforts through intensive technical assistance in all of the policy areas covered by the SMP. The more immediate and macroeconomic focus of the SMP's policies will complement planned engagement by the World Bank and AsDB on structural reforms to boost long-term growth. 
Table 1. Myanmar: Selected Economic Indicators, 2007/08-2012/13 1/

GDP (2010/11): US $\$ 45.4$ billion 2/

Population (2007/08): 57.5 million

Quota: SDR 258.4 million

$\begin{array}{llllll}2007 / 08 & 2008 / 09 & 2009 / 10 \quad 2010 / 11 & 2011 / 12 & 2012 / 13 \\ & & \end{array}$

Est. $\quad$ Est. Proj. 3/

Real GDP and prices

Real GDP

Staff working estimates of real GDP

Agriculture 4/

Industrial production 5/

Services and trade

Consumer prices (period average)

Consumer prices (end of period)

Public sector operations 6/

Total revenue (including grants)

Total expenditure 7/

Overall balance

Central bank financing

Domestic public debt

Money and credit

Broad money

Domestic credit

Government (net)

Credit to private sector

(Percent change; unless otherwise indicated)

alance of payments

Trade balance

Exports

Imports

Current account balance (excluding grants)

(In percent of GDP) 2/

Overall balance

Gross official reserves

In millions of U.S. dollars

In months of total imports

External debt

Total external debt (including arrears)

(In percent of GDP) 2/

External debt arrears 7/

Terms of trade (in percent change)

Exchange rates (end of period)

Official exchange rate (kyat per U.S. dollar)

Parallel rate (kyat per U.S. dollar) 8/

Central bank reference rate (kyat per U.S. dollar) 8/

$\begin{array}{lrrr}12.0 & 10.3 & 10.6 & 10.4\end{array}$

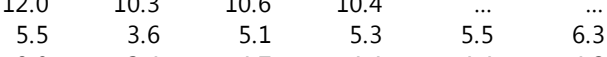

$\begin{array}{llllll}8.0 & 3.4 & 4.7 & 4.4 & 4.4 & 4.2\end{array}$

$\begin{array}{llllll}21.8 & 3.0 & 5.0 & 6.3 & 6.5 & 7.2\end{array}$

$\begin{array}{rrrrrr}12.9 & 4.2 & 5.8 & 6.1 & 6.3 & 8.5 \\ 32.9 & 22.5 & 8.2 & 8.2 & 4.0 & 6.1\end{array}$

$\begin{array}{rrrrrr}32.9 & 22.5 & 8.2 & 8.2 & 4.0 & 6.1 \\ 28.8 & 9.2 & 7.1 & 8.9 & 5.0 & 6.1\end{array}$

(In percent of GDP)

$\begin{array}{llllll}14.1 & 13.0 & 11.7 & 13.0 & 13.0 & 19.3\end{array}$

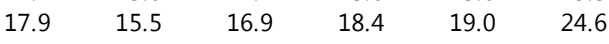

$\begin{array}{llllll}-3.8 & -2.4 & -5.2 & -5.5 & -6.0 & -5.3 \\ 2.7 & 3.0 & 3.1 & -4.2 & -2.8 & 1.6\end{array}$

$\begin{array}{rrrrrr}2.7 & 3.0 & 3.1 & 4.2 & 2.8 & 1.6\end{array}$

$\begin{array}{llllll}16.4 & 16.7 & 19.9 & 22.9 & 25.1 & 25.3\end{array}$

(Annual percentage change)

$\begin{array}{llllll}21.0 & 23.4 & 34.8 & 36.3 & 26.3 & 28.6\end{array}$

$\begin{array}{llllll}22.1 & 24.0 & 34.8 & 34.4 & 25.1 & 28.0\end{array}$

$\begin{array}{llllll}23.3 & 25.6 & 34.4 & 28.5 & 16.6 & 14.0\end{array}$

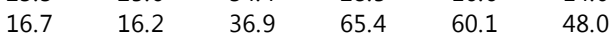

(In millions of U.S. dollars, unless otherwise indicated)

$\begin{array}{lrlllll}\text { GDP in billions of kyats } & 23,336 & 28,778 & 32,351 & 36,436 & 39,719 & 44,797\end{array}$

GDP in millions of U.S. dollars 2/ $\quad 20,182 \quad 31,367 \quad 35,225 \quad 45,380 \quad 51,444 \quad 53,140$

Sources: Until FY2009/10 the authorities, with some adjustments by IMF staff; from FY2010/11 IMF staff estimations and projections.

1/ Fiscal year (April-March).

2/ Before FY2012/13, GDP converted at a weighted exchange rate, where the official and FEC market rates are weighted with about 8 and 92 percent, based on the respective shares of public and private sectors in GDP.

3/ The authorities adopted a managed float on April 1, 2012.

$4 /$ Including livestock, fishery, and forestry.

5 / Including manufacturing, power, energy, construction, and mining.

6/ Consolidated public sector; includes the Union government and state economic enterprises.

7/ For 2012/13 incorporates the terms of bilateral arrears clearance agreement with Japan, World Bank and AsDB.

8/ The exchange rate for FY2012/13 is as of November, 16, 2011. 


\begin{tabular}{|c|c|c|c|c|c|c|c|c|c|c|c|}
\hline & $2007 / 08$ & 2008/09 & $2009 / 10$ & 2010/11 & 2011/12 & 2012/13 1/ & 2013/14 & 2014/15 & $2015 / 16$ & 2016/17 & $2017 / 18$ \\
\hline & & & Prel. & Prel. & Est. & Proj. & Proj. & Proj. & Proj. & Proj. & Proj. \\
\hline & \multicolumn{11}{|c|}{ (In billons of kyats) } \\
\hline \multicolumn{12}{|l|}{ Union government } \\
\hline Revenue & 1,703 & 2,078 & 2,028 & 2,542 & 2,784 & 3,082 & 3,500 & 3,967 & 4,557 & 5,203 & 5,954 \\
\hline Tax revenue 2/ & 875 & 1,045 & 1,077 & 1,318 & 1,610 & 1,888 & 2,177 & 2,540 & 3,026 & 3,555 & 4,177 \\
\hline Transfers from state economic enterprises & 686 & 807 & 793 & 783 & 1,040 & 843 & 902 & 952 & 997 & 1,050 & 1,109 \\
\hline Other nontax revenue $3 /$ & 142 & 225 & 158 & 440 & 135 & 258 & 290 & 322 & 358 & 399 & 444 \\
\hline Foreign grants $4 /$ & 0.2 & 0.3 & 0.5 & 0.3 & 0.2 & 93.6 & 131.7 & 153.2 & 175.7 & 199.2 & 223.8 \\
\hline Expenditures & 2,161 & 2,269 & 3,175 & 4,379 & 4,719 & 7,133 & 8,146 & 9,207 & 10,363 & 11,709 & 13,202 \\
\hline Current expenditures & 812 & 937 & 1,159 & 1,548 & 2,079 & 3,695 & 4,209 & 4,746 & 5,339 & 6,044 & 6,854 \\
\hline Wages/salaries & 262 & 263 & 310 & 435 & 519 & 733 & 824 & 916 & 1,019 & 1,134 & 1,264 \\
\hline Goods and services & 84 & 99 & 102 & 132 & 284 & 294 & 331 & 368 & 409 & 456 & 507 \\
\hline Maintenance and repairs & 42 & 76 & 67 & 10 & 174 & 262 & 294 & 327 & 364 & 406 & 452 \\
\hline Contributions & 6 & 46 & 61 & 73 & 250 & 434 & 462 & 514 & 572 & 637 & 709 \\
\hline Interest payments & 147 & 181 & 263 & 359 & 467 & 669 & 834 & 994 & 1,165 & 1,396 & 1,677 \\
\hline Domestic & 146 & 181 & 263 & 359 & 466 & 570 & 683 & 820 & 972 & 1,180 & 1,443 \\
\hline External (due) 4/ & 0.2 & 0.2 & 0.4 & 0.3 & 0.4 & 99.1 & 151.3 & 173.3 & 193.1 & 216.1 & 233.9 \\
\hline Other 5/ & 271 & 272 & 328 & 539 & 385 & 1,303 & 1,464 & 1,627 & 1,810 & 2,016 & 2,245 \\
\hline Capital expenditures & 1,349 & 1,332 & 2,016 & 2,831 & 2,640 & 3,438 & 3,937 & 4,461 & 5,024 & 5,665 & 6,348 \\
\hline Current balance & 891 & 1,141 & 869 & 994 & 705 & -614 & -709 & -779 & -782 & -841 & -900 \\
\hline Overall balance & -458 & -192 & $-1,147$ & $-1,837$ & $-1,935$ & $-4,051$ & $-4,646$ & $-5,240$ & $-5,807$ & $-6,506$ & $-7,249$ \\
\hline \multicolumn{12}{|l|}{ State economic enterprises } \\
\hline Receipts & 2,268 & 2,482 & 2,542 & 2,977 & 3,400 & 6,413 & 7,354 & 8,345 & 9,406 & 10,614 & 11,977 \\
\hline Expenditures & 2,702 & 2,988 & 3,081 & 3,126 & 3,856 & 4,733 & 5,317 & 5,911 & 6,575 & 7,323 & 8,156 \\
\hline Current & 2,431 & 2,637 & 2,669 & 2,754 & 3,444 & 3,807 & 4,276 & 4,755 & 5,288 & 5,890 & 6,560 \\
\hline Capital & 270 & 351 & 412 & 372 & 412 & 926 & 1,040 & 1,157 & 1,287 & 1,433 & 1,596 \\
\hline Current balance & -163 & -155 & -127 & 223 & -44 & 2,606 & 3,078 & 3,590 & 4,118 & 4,724 & 5,417 \\
\hline Overall balance & -434 & -506 & -539 & -149 & -456 & 1,680 & 2,037 & 2,433 & 2,831 & 3,291 & 3,821 \\
\hline \multicolumn{12}{|l|}{ Consolidated accounts } \\
\hline Revenue 6/ & 3,285 & 3,753 & 3,777 & 4,736 & 5,144 & 8,652 & 9,952 & 11,360 & 12,966 & 14,767 & 16,822 \\
\hline Of which: Revenue from gas exports & 7 & 9 & 8 & 10 & 12 & 1,952 & 2,254 & 2,672 & 2,645 & 2,708 & 2,758 \\
\hline $\operatorname{Tax}$ & 875 & 1,045 & 1,077 & 1,318 & 1,610 & 1,888 & 2,177 & 2,540 & 3,026 & 3,555 & 4,177 \\
\hline Nontax & 2,410 & 2,707 & 2,700 & 3,418 & 3,534 & 6,671 & 7,643 & 8,667 & 9,764 & 11,013 & 12,421 \\
\hline Grants 4/ & 0.2 & 0.3 & 0.5 & 0.3 & 0.2 & 93.6 & 131.7 & 153.2 & 175.7 & 199.2 & 223.8 \\
\hline Expenditures & 4,177 & 4,450 & 5,463 & 6,722 & 7,536 & 11,024 & 12,560 & 14,167 & 15,941 & 17,982 & 20,250 \\
\hline Current 6/ & 2,557 & 2,767 & 3,035 & 3,519 & 4,483 & 6,660 & 7,583 & 8,549 & 9,630 & 10,884 & 12,305 \\
\hline Capital & 1,620 & 1,683 & 2,428 & 3,203 & 3,053 & 4,364 & 4,977 & 5,618 & 6,311 & 7,098 & 7,945 \\
\hline Current balance & 728 & 985 & 743 & 1,217 & 661 & 1,992 & 2,369 & 2,811 & 3,335 & 3,883 & 4,517 \\
\hline Overall balance & -892 & -697 & $-1,686$ & $-1,986$ & $-2,391$ & $-2,372$ & $-2,608$ & $-2,807$ & $-2,976$ & $-3,214$ & $-3,428$ \\
\hline
\end{tabular}




\begin{tabular}{|c|c|c|c|c|c|c|c|c|c|c|c|}
\hline & 2007/08 & 2008/09 & $2009 / 10$ & 2010/11 & 2011/12 & 2012/13 1/ & 2013/14 & 2014/15 & 2015/16 & 2016/17 & $2017 / 18$ \\
\hline & & & Prel. & Prel. & Est. & Proj. & Proj. & Proj. & Proj. & Proj. & Proj. \\
\hline & \multicolumn{11}{|c|}{ (In billons of kyats) } \\
\hline Financing & 892 & 697 & 1,686 & 1,986 & 2,391 & 2,372 & 2,608 & 2,807 & 2,976 & 3,214 & 3,428 \\
\hline Foreign financing & 2.0 & 1.7 & 1.6 & 1.1 & 1.6 & 960.0 & $1,046.5$ & $1,151.5$ & $1,260.6$ & $1,290.5$ & $1,483.3$ \\
\hline Foreign loans (net on accrual basis) 4/ & 0.4 & -0.9 & -1.3 & -1.75 & -0.7 & 960.0 & $1,046.5$ & $1,151.5$ & $1,260.6$ & $1,290.5$ & $1,483.3$ \\
\hline Disbursements 7/ & 1.3 & 1.1 & 1.0 & 0.7 & 1.1 & $1,200.2$ & $1,366.7$ & $1,501.7$ & $1,627.0$ & $1,789.5$ & $1,949.4$ \\
\hline Amortization due 8/ & -0.8 & -2.0 & -2.3 & -2.5 & -1.8 & -240.1 & -320.2 & -350.2 & -366.3 & -499.0 & -466.1 \\
\hline Change in external arrears 4/ & 1.6 & 2.7 & 2.9 & 2.9 & 2.3 & 0.0 & 0.0 & 0.0 & 0.0 & 0.0 & 0.0 \\
\hline Interest & 1.2 & 1.3 & 1.3 & 1.2 & 1.2 & 0.0 & 0.0 & 0.0 & 0.0 & 0.0 & 0.0 \\
\hline Principal & 0.4 & 1.3 & 1.6 & 1.7 & 1.1 & 0.0 & 0.0 & 0.0 & 0.0 & 0.0 & 0.0 \\
\hline Domestic financing & 890 & 696 & 1,684 & 1,985 & 2,390 & 1,412 & 1,562 & 1,655 & 1,715 & 1,924 & 1,945 \\
\hline Central bank credit & 641 & 852 & 1,004 & 1,522 & 1,131 & 702 & 468 & 331 & 172 & 96 & 10 \\
\hline Bank financing & 62 & 118 & 640 & 371 & 527 & 651 & 1,064 & 1,322 & 1,541 & 1,825 & 1,932 \\
\hline \multirow[t]{2}{*}{ Other $9 /$} & 187 & -274 & 40 & 92 & 733 & 59 & 30 & 2 & 3 & 3 & 3 \\
\hline & \multicolumn{11}{|c|}{ (In percent of GDP) } \\
\hline \multicolumn{12}{|l|}{ Consolidated accounts } \\
\hline Revenue & 14.1 & 13.0 & 11.7 & 13.0 & 13.0 & 19.3 & 19.8 & 20.3 & 20.8 & 21.3 & 21.8 \\
\hline Of which: Revenue from gas exports & 0.0 & 0.0 & 0.0 & 0.0 & 0.0 & 4.4 & 4.5 & 4.8 & 4.3 & 3.9 & 3.6 \\
\hline Tax & 3.7 & 3.6 & 3.3 & 3.6 & 4.1 & 4.2 & 4.3 & 4.5 & 4.9 & 5.1 & 5.4 \\
\hline Nontax & 10.3 & 9.4 & 8.3 & 9.4 & 8.9 & 14.9 & 15.2 & 15.5 & 15.7 & 15.9 & 16.1 \\
\hline Grants 4/ & 0.0 & 0.0 & 0.0 & 0.0 & 0.0 & 0.2 & 0.3 & 0.3 & 0.3 & 0.3 & 0.3 \\
\hline Total expenditures & 17.9 & 15.5 & 16.9 & 18.4 & 19.0 & 24.6 & 25.0 & 25.3 & 25.6 & 25.9 & 26.2 \\
\hline Current expenditures & 11.0 & 9.6 & 9.4 & 9.7 & 11.3 & 14.9 & 15.1 & 15.3 & 15.5 & 15.7 & 15.9 \\
\hline Current balance & 3.1 & 3.4 & 2.3 & 3.3 & 1.7 & 4.4 & 4.7 & 5.0 & 5.4 & 5.6 & 5.9 \\
\hline Capital expenditures & 6.9 & 5.8 & 7.5 & 8.8 & 7.7 & 9.7 & 9.9 & 10.0 & 10.1 & 10.2 & 10.3 \\
\hline Overall balance & -3.8 & -2.4 & -5.2 & -5.5 & -6.0 & -5.3 & -5.2 & -5.0 & -4.8 & -4.6 & -4.4 \\
\hline Of which: Bank financing & 0.3 & 0.4 & 2.0 & 1.0 & 1.3 & 1.5 & 2.1 & 2.4 & 2.5 & 2.6 & 2.5 \\
\hline Defense spending & 1.6 & 1.6 & 2.3 & 4.5 & 3.7 & 6.1 & $\ldots$ & $\ldots$ & $\ldots$ & $\ldots$ & $\ldots$ \\
\hline \multirow[t]{2}{*}{ Social spending excluding pensions } & 1.1 & 1.0 & 1.1 & 1.4 & 1.4 & 4.6 & $\ldots$ & $\ldots$ & $\ldots$ & $\ldots$ & $\ldots$ \\
\hline & \multicolumn{11}{|c|}{ (In percent of total expenditure) } \\
\hline Defense expenditure & 17.8 & 20.5 & 23.3 & 37.5 & 31.0 & 38.4 & $\ldots$ & $\ldots$ & $\ldots$ & $\ldots$ & $\ldots$ \\
\hline Social sector spending excluding pensions & 12.0 & 13.3 & 10.9 & 11.7 & 12.0 & 29.0 & $\ldots$ & $\ldots$ & $\ldots$ & $\ldots$ & $\ldots$ \\
\hline \multicolumn{12}{|c|}{ Sources: Budget Department, Ministry of Finance and Revenue; and IMF staff estimates and projections. } \\
\hline \multicolumn{12}{|c|}{$\begin{array}{l}\text { 1/ The authorities adopted managed float in FY2012/13. } \\
\text { 2/ From FY2011/12, includes property and wheel tax. From FY2009/10, includes state lottery revenues, which had been in other nontax revenue. } \\
\text { 3/ From FY2011/12, other nontax revenue include certain local development councils (eg. Yangon, Mandalay, etc.), which were not included earlier. } \\
\text { 4/ Converted at the official exchange rate before FY 2012/13, when the official exchange rate is replaced by a market-determined exchange rate. } \\
\text { 5/ Includes current expenditures of the Ministry of Defense and pension and gratuities. } \\
6 \text { / Consolidated revenue includes all revenue receipts of union government and SEEs. Consolidated current expenditures include current expenditures of union government and SEEs. } \\
\text { 7/ Includes additional loans from bilateral and multilateral creditors. } \\
\text { 8/ Includes payments of principal on loans that still exists after the arrears clearance and that are associated with rescheduling. } \\
\text { 9/ Includes privatization receipts, sales of government assets, and statistical discrepancy. }\end{array}$} \\
\hline
\end{tabular}




\begin{tabular}{|c|c|c|c|c|c|c|c|}
\hline \multicolumn{8}{|c|}{$\begin{array}{l}\text { Table 3. Myanmar: Monetary Survey, 2007/08-2012/13 1/ } \\
\text { (In billions of kyat at end-period, unless otherwise indiacted) }\end{array}$} \\
\hline & $2007 / 08$ & $2008 / 09$ & $2009 / 10$ & 2010/11 & $2011 / 12$ & $\frac{2012 / 132 /}{\text { Proj. }}$ & $\frac{2013 / 142 /}{\text { Proj. }}$ \\
\hline \multicolumn{8}{|l|}{ CENTRAL BANK OF MYANMAR (CBM) } \\
\hline Net foreign assets & -1.9 & -1.8 & -1.6 & -1.6 & -1.4 & 1,238 & 3,911 \\
\hline Foreign assets & 1.2 & 1.2 & 2.9 & 2.9 & 3.0 & 2,338 & 5,059 \\
\hline Foreign liabilities & 3.1 & 3.0 & 4.5 & 4.5 & 4.4 & 1,100 & 1,148 \\
\hline Net domestic assets & 3,564 & 4,189 & 5,365 & 7,003 & 7,553 & 8,354 & 6,142 \\
\hline Domestic credit & 3,653 & 4,301 & 5,518 & 7,162 & 7,851 & 9,116 & 6,902 \\
\hline Claims on central government (net) & 3,641 & 4,287 & 5,476 & 6,883 & 7,673 & 8,376 & 8,844 \\
\hline Claims on deposit money banks & 12 & 14 & 42 & 279 & 178 & 740 & $-1,942$ \\
\hline Other items net & -89 & -113 & -153 & -159 & -299 & -762 & -760 \\
\hline Of which: Valuation gain (-)/losses (+) 3/ & $\ldots$ & & $\ldots$ & & $\ldots$ & -622 & \\
\hline Reserve money & 3,562 & 4,187 & 5,363 & 7,001 & 7,551 & 8,742 & 10,053 \\
\hline Currency in circulation & 2,954 & 3,375 & 4,232 & 5,227 & 6,070 & 6,731 & 7,640 \\
\hline Deposits & 608 & 812 & 1,131 & 1,774 & 1,481 & 2,011 & 2,413 \\
\hline \multicolumn{8}{|l|}{ MONETARY SURVEY } \\
\hline Net foreign assets & -2 & 2 & 4 & 6 & 25 & 3,037 & 4,666 \\
\hline Foreign assets & 16 & 21 & 26 & 30 & 49 & 4,287 & 6,014 \\
\hline Foreign liabilities & 18 & 19 & 22 & 24 & 24 & 1,250 & 1,348 \\
\hline Net domestic assets & 4,394 & 5,419 & 7,301 & 9,951 & 12,548 & 13,135 & 15,301 \\
\hline Domestic credit & 4,607 & 5,712 & 7,700 & 10,348 & 12,948 & 16,579 & 20,512 \\
\hline Net claims on government & 3,830 & 4,810 & 6,466 & 8,310 & 9,688 & 11,041 & 12,573 \\
\hline CBM & 3,641 & 4,287 & 5,476 & 6,883 & 7,673 & 8,376 & 8,844 \\
\hline Deposit money banks & 189 & 523 & 990 & 1,427 & 2,015 & 2,666 & 3,729 \\
\hline Credit to the economy & 777 & 902 & 1,234 & 2,038 & 3,260 & 5,538 & 7,939 \\
\hline Private sector & 773 & 898 & 1,229 & 2,033 & 3,255 & 4,818 & 6,986 \\
\hline Other & 4 & 5 & 5 & 5 & 5 & 720 & 953 \\
\hline Other items net & -213 & -294 & -399 & -397 & -400 & $-3,444$ & $-5,211$ \\
\hline Of which: Valuation gain (-)/losses (+) 3/ & $\ldots$ & $\ldots$ & $\ldots$ & $\ldots$ & $\ldots$ & $-2,818$ & \\
\hline Broad money & 4,392 & 5,421 & 7,305 & 9,958 & 12,573 & 16,172 & 19,967 \\
\hline Currency outside banks & 2,811 & 3,194 & 4,009 & 4,825 & 5,563 & 6,792 & 7,987 \\
\hline Deposits & 1,582 & 2,227 & 3,296 & 5,132 & 7,010 & 9,380 & 11,980 \\
\hline \multicolumn{8}{|l|}{ MEMORANDUM ITEMS } \\
\hline Money multiplier & 1.2 & 1.3 & 1.4 & 1.4 & 1.7 & 1.9 & 2.0 \\
\hline Velocity & 5.3 & 5.3 & 4.4 & 3.7 & 3.2 & 2.8 & 2.5 \\
\hline Reserve money (y/y percent change) & 20.8 & 17.6 & 28.1 & 30.5 & 7.9 & 15.8 & 15.0 \\
\hline Broad money (y/y percent change) & 21.0 & 23.4 & 34.8 & 36.3 & 26.3 & 28.6 & 23.5 \\
\hline Broad money (in percent of GDP) & 18.8 & 18.8 & 22.6 & 27.3 & 31.7 & 36.1 & 39.7 \\
\hline Credit to government outstanding (share of CBM) & 95.1 & 89.1 & 84.7 & 82.8 & 79.2 & 75.9 & 70.3 \\
\hline Credit to private sector (in percent of GDP) & 3.3 & 3.1 & 3.8 & 5.6 & 8.2 & 10.8 & 13.9 \\
\hline Credit to private sector (y/y percent change) & 16.7 & 16.2 & 36.9 & 65.4 & 60.1 & 48.0 & 45.0 \\
\hline Deposits (in percent of GDP) & 6.8 & 7.7 & 10.2 & 14.1 & 17.6 & 20.9 & 23.8 \\
\hline Credit to economy/deposits (in percent) & 49.1 & 40.5 & 37.4 & 39.7 & 46.5 & 59.0 & 66.3 \\
\hline Exchange rate (kyat $/ \$$, end of period) & 5.22 & 5.77 & 5.66 & 5.44 & 5.56 & $\ldots$ & \\
\hline Nominal GDP (in billions of kyat) & 23,336 & 28,778 & 32,351 & 36,436 & 39,719 & 44,797 & 50,318 \\
\hline \multicolumn{8}{|c|}{ Sources: Central Bank of Myanmar, and IMF staff estimates and projections. } \\
\hline $\begin{array}{l}\text { 1/ The fiscal year ends on March } 31 . \\
2 \text { / Foreign assets and liabilites valued at market-det } \\
3 \text { / Due to adoption of market-determined exchange }\end{array}$ & efore: va & $d$ at offic & 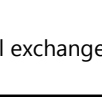 & & & & \\
\hline
\end{tabular}




\begin{tabular}{|c|c|c|c|c|c|c|c|c|c|c|c|}
\hline \multicolumn{12}{|c|}{$\begin{array}{l}\text { Table 4. Myanmar: Balance of Payments, 2007/08-2017/18 } \\
\text { (In millions of U.S. dollars, unless otherwise indicated) }\end{array}$} \\
\hline \multirow[b]{2}{*}{$\begin{array}{l}\text { Current account } \\
\text { Current account, excluding grants }\end{array}$} & \multirow{2}{*}{$\begin{array}{r}2007 / 08 \\
\\
-57 \\
-99\end{array}$} & \multirow{2}{*}{$\begin{array}{r}2008 / 09 \\
-978 \\
-1,038\end{array}$} & \multirow{2}{*}{$\begin{array}{r}2009 / 10 \\
-906 \\
-991\end{array}$} & \multirow{2}{*}{$\begin{array}{r}2010 / 11 \\
-526 \\
-590\end{array}$} & \multirow{2}{*}{$\begin{array}{c}\frac{2011 / 12}{\text { Est. }} \\
-1,299 \\
-1,331\end{array}$} & \multirow{2}{*}{$\begin{array}{r}2012 / 13 \\
-2,010 \\
-2,120\end{array}$} & \multirow{2}{*}{$\begin{array}{r}2013 / 14 \\
\\
\\
\\
-2,280 \\
-2,429\end{array}$} & \multirow{2}{*}{$\begin{array}{c}2014 / 15 \\
\text { Proj. } \\
\\
-2,844 \\
-3,012\end{array}$} & \multirow{2}{*}{$\begin{array}{r}2015 / 16 \\
-3,230 \\
-3,419\end{array}$} & \multirow{2}{*}{$\begin{array}{r}2016 / 17 \\
\\
\\
-3,670 \\
-3,879\end{array}$} & \multirow{2}{*}{$\begin{array}{r}2017 / 18 \\
\\
-4,153 \\
-4,381\end{array}$} \\
\hline & & & & & & & & & & & \\
\hline Trade balance & 924 & 302 & 72 & 796 & -10 & $-1,313$ & $-1,077$ & -776 & $-1,300$ & $-2,082$ & $-2,924$ \\
\hline Exports, mainly f.o.b. & 6,446 & 7,241 & 7,139 & 8,980 & 10,170 & 11,308 & 12,907 & 15,170 & 16,475 & 18,223 & 20,426 \\
\hline Public exports & 4,061 & 4,562 & 4,105 & 5,388 & 5,593 & 6,101 & 7,415 & 8,723 & 9,556 & 10,497 & 11,623 \\
\hline Of which: Gas & 2,282 & 2,849 & 2,480 & 2,657 & 3,282 & 3,538 & 4,444 & 5,891 & 5,754 & 5,569 & 5,422 \\
\hline Private exports & 2,256 & 2,607 & 2,963 & 3,502 & 4,576 & 5,207 & 5,492 & 6,447 & 6,920 & 7,727 & 8,804 \\
\hline Imports, mainly c.i.f. & 5,522 & 6,938 & 7,067 & 8,184 & 10,180 & 12,621 & 13,984 & 15,946 & 17,775 & 20,305 & 23,351 \\
\hline Private imports & 4,031 & 5,551 & 4,947 & 5,892 & 6,617 & 8,077 & 9,229 & 10,843 & 12,620 & 14,721 & 17,279 \\
\hline Services, net & $-1,251$ & $-1,675$ & $-1,334$ & $-1,636$ & $-1,586$ & $-1,099$ & $-1,687$ & $-2,598$ & $-2,510$ & $-2,219$ & $-1,913$ \\
\hline Receipts & 478 & 487 & 487 & 543 & 584 & 589 & 675 & 761 & 834 & 929 & 1,041 \\
\hline Payments & 1,729 & 2,161 & 1,821 & 2,179 & 2,170 & 1,688 & 2,361 & 3,359 & 3,343 & 3,148 & 2,953 \\
\hline Of which: Interest due & 250 & 254 & 237 & 236 & 245 & 117 & 173 & 193 & 210 & 229 & 242 \\
\hline Private transfers, net & 227 & 334 & 270 & 250 & 265 & 292 & 335 & 362 & 391 & 422 & 456 \\
\hline Official grants & 42 & 60 & 85 & 64 & 33 & 110 & 148 & 168 & 188 & 208 & 228 \\
\hline Nonmonetary capital movements & 644 & 372 & 1,098 & 2,673 & 1,397 & 3,133 & 2,906 & 3,281 & 3,968 & 4,416 & 4,932 \\
\hline Long term, net & 79 & -157 & -230 & -322 & -134 & 1,128 & 1,195 & 1,281 & 1,368 & 1,366 & 1,532 \\
\hline Disbursements & 242 & 185 & 180 & 133 & 219 & 1,410 & 1,560 & 1,670 & 1,765 & 1,895 & 2,014 \\
\hline Repayments due & 163 & 342 & 410 & 455 & 353 & 282 & 366 & 389 & 398 & 528 & 481 \\
\hline Foreign direct investment & 715 & 976 & 963 & 969 & 1,992 & 2,325 & 1,811 & 2,050 & 2,600 & 3,000 & 3,350 \\
\hline Other capital, net $1 /$ & -150 & -447 & 365 & 2,026 & -461 & -320 & -100 & -50 & 0 & 50 & 50 \\
\hline Errors and omissions, net & -348 & 202 & -220 & $-2,480$ & -620 & 0 & 0 & 0 & 0 & 0 & 0 \\
\hline Overall balance & 239 & -405 & -28 & -333 & -522 & 1,124 & 626 & 437 & 738 & 746 & 779 \\
\hline Financing & -239 & 405 & 28 & 333 & 522 & $-1,124$ & -626 & -437 & -738 & -746 & -779 \\
\hline Net international reserves (- increase) & -675 & -254 & -687 & -427 & -536 & $-1,253$ & -626 & -437 & -738 & -746 & -779 \\
\hline Gross reserves (- increase) & -634 & -215 & -655 & -400 & -509 & $-1,253$ & -626 & -437 & -738 & -746 & -779 \\
\hline Of which: SDR allocation & & & 320 & & & & & & $\ldots$ & & \\
\hline Short-term liabilities & -41 & -39 & -32 & -27 & -27 & 0 & 0 & 0 & 0 & 0 & 0 \\
\hline Net increase in arrears & 436 & 659 & 715 & 760 & 1,058 & $-8,632$ & $-2,372$ & 0 & 0 & 0 & 0 \\
\hline Exceptional Financing & 0 & 0 & 0 & 0 & 0 & 8,632 & 2,372 & 0 & 0 & 0 & 0 \\
\hline Cancellation of arrears & 0 & 0 & 0 & 0 & 0 & 3,458 & 2,372 & 0 & 0 & 0 & 0 \\
\hline Rescheduling of Arrears & 0 & 0 & 0 & 0 & 0 & 5,174 & 0 & 0 & 0 & 0 & 0 \\
\hline \multicolumn{12}{|l|}{ Memorandum items: } \\
\hline Current account balance (in percent of GDP 2/3/) & -0.5 & -3.3 & -2.8 & -1.3 & -2.6 & -4.1 & -4.2 & -4.8 & -5.1 & -5.3 & -5.5 \\
\hline Export volumes (percent change) & $\ldots$ & -1.3 & 2.2 & 32.3 & 1.1 & 8.0 & 12.7 & 16.6 & 9.9 & 11.6 & 12.9 \\
\hline Import volumes (percent change) & $\ldots$ & 22.1 & 6.5 & 11.8 & 18.5 & 24.1 & 11.1 & 14.1 & 11.2 & 13.6 & 13.7 \\
\hline Gross reserves, end-period & 2,039 & 2,254 & 2,909 & 3,309 & 3,818 & 5,071 & 5,697 & 6,134 & 6,871 & 7,617 & 8,397 \\
\hline (In months of prospective GNFS imports) & 3.2 & 3.5 & 3.8 & 3.5 & 3.3 & 4.0 & 3.9 & 3.8 & 3.8 & 3.6 & 3.5 \\
\hline Net reserves, end-period & 1,758 & 2,012 & 2,699 & 3,126 & 3,662 & 4,915 & 5,541 & 5,978 & 6,715 & 7,461 & 8,241 \\
\hline Total external debt & 12,305 & 12,744 & 13,207 & 13,643 & 14,632 & 12,251 & 11,230 & 12,666 & 14,190 & 15,713 & 17,401 \\
\hline (In percent of GDP 2/3/) & 61.0 & 40.6 & 37.5 & 30.1 & 27.8 & 23.6 & 19.8 & 20.6 & 21.3 & 21.7 & 22.1 \\
\hline Ratio of external debt to exports of goods and nonfactor services & 1.8 & 1.7 & 1.7 & 1.4 & 1.4 & 1.0 & 0.8 & 0.8 & 0.8 & 0.8 & 0.8 \\
\hline External debt arrears & 8,365 & 8,825 & 9,323 & 9,850 & 10,592 & 2,372 & 0 & 0 & 0 & 0 & 0 \\
\hline External debt service (in percent of goods and nonfactor & & & & & & & & & & & \\
\hline service exports) & 6.1 & 6.4 & 6.6 & 5.1 & 8.5 & 1.9 & 1.8 & 2.4 & 2.6 & 2.5 & 1.3 \\
\hline Ratio of broad money (M2) to gross reserves & 1.9 & 2.4 & 2.5 & 3.5 & 4.0 & 3.7 & 3.9 & 3.8 & 3.7 & 3.7 & 3.7 \\
\hline Terms of trade (percent change) & -1.1 & 2.8 & 4.5 & -7.5 & 7.1 & 3.4 & 1.8 & 1.3 & -1.3 & -1.2 & -1.7 \\
\hline \multicolumn{12}{|c|}{ Sources: Data provided by the Myanmar authorities; and IMF staff estimates and projections. } \\
\hline Converted at the official exchange rate hefore FYa12/13 w & the 2009 & ecialo & a-time & 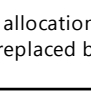 & . & . & & & & & \\
\hline
\end{tabular}


Table 5. Myanmar: Medium-Term Projections, 2007/08-2017/18

\begin{tabular}{|c|c|c|c|c|c|c|c|c|c|c|c|}
\hline & $2007 / 08$ & 2008/09 & $2009 / 10$ & $\frac{2010 / 11}{\text { Est. }}$ & 2011/12 & $2012 / 13$ & 2013/14 & 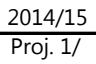 & $2015 / 16$ & $2016 / 17$ & $2017 / 18$ \\
\hline & \multicolumn{11}{|c|}{ (Percentage change) } \\
\hline GDP (in constant prices) & 12.0 & 10.3 & 10.6 & 10.4 & $\ldots$ & $\ldots$ & $\ldots$ & $\ldots$ & $\ldots$ & $\ldots$ & $\ldots$ \\
\hline Staff working estimates of real GDP & 5.5 & 3.6 & 5.1 & 5.3 & 5.5 & 6.3 & 6.5 & 6.6 & 6.7 & 6.8 & 6.9 \\
\hline Agriculture 2/ & 8.0 & 3.4 & 4.7 & 4.4 & 4.4 & 4.2 & 4.9 & 5.0 & 5.3 & 5.4 & 5.4 \\
\hline Industrial production $3 /$ & 21.8 & 3.0 & 5.0 & 6.3 & 6.5 & 7.2 & 7.2 & 7.2 & 7.2 & 7.6 & 7.6 \\
\hline Services and trade & 12.9 & 4.2 & 5.8 & 6.1 & 6.3 & 8.5 & 8.0 & 8.1 & 8.1 & 8.1 & 8.1 \\
\hline \multirow[t]{2}{*}{ Inflation (CPI, end of period) } & 28.8 & 9.2 & 7.1 & 8.9 & 5.0 & 6.1 & 5.3 & 5.0 & 5.0 & 5.0 & 5.0 \\
\hline & \multicolumn{11}{|c|}{ (In percent of GDP) } \\
\hline \multicolumn{12}{|l|}{ Public finances } \\
\hline Total revenue (including grants) & 14.1 & 13.0 & 11.7 & 13.0 & 13.0 & 19.3 & 19.8 & 20.3 & 20.8 & 21.3 & 21.8 \\
\hline Total expenditure & 17.9 & 15.5 & 16.9 & 18.4 & 19.0 & 24.6 & 25.0 & 25.3 & 25.6 & 25.9 & 26.2 \\
\hline Of which: Capital expenditure & 6.9 & 5.8 & 7.5 & 8.8 & 7.7 & 9.7 & 9.9 & 10.0 & 10.1 & 10.2 & 10.3 \\
\hline Overall balance & -3.8 & -2.4 & -5.2 & -5.5 & -6.0 & -5.3 & -5.2 & -5.0 & -4.8 & -4.6 & -4.4 \\
\hline Estimated domestic public debt & 16.4 & 16.7 & 19.9 & 22.9 & 25.1 & 25.3 & 25.6 & 26.0 & 26.1 & 26.2 & 26.0 \\
\hline \multirow[t]{2}{*}{ Estimated total public debt } & 77.3 & 57.3 & 57.4 & 52.9 & 53.6 & 48.4 & 45.1 & 46.3 & 47.1 & 47.6 & 47.9 \\
\hline & \multicolumn{11}{|c|}{ (In millions of U.S. dollars, unless otherwise indicated) } \\
\hline \multicolumn{12}{|l|}{ Balance of payments } \\
\hline Exports (in percentage change) & 23.9 & 12.3 & -1.4 & 25.8 & 13.3 & 11.2 & 14.1 & 17.5 & 8.6 & 10.6 & 12.1 \\
\hline Imports (in percentage change) & 88.0 & 25.6 & 1.8 & 15.8 & 24.4 & 24.0 & 10.8 & 14.0 & 11.5 & 14.2 & 15.0 \\
\hline Trade balance & 924 & 302 & 72 & 796 & -10 & $-1,313$ & $-1,077$ & -776 & $-1,300$ & $-2,082$ & $-2,924$ \\
\hline (In percent of GDP) 4/ & 4.6 & 1.0 & 0.2 & 1.8 & 0.0 & -2.5 & -1.9 & -1.2 & -1.9 & -2.8 & -3.7 \\
\hline Current account (excluding grants) & -99 & $-1,038$ & -991 & -590 & $-1,331$ & $-2,120$ & $-2,429$ & $-3,012$ & $-3,419$ & $-3,879$ & $-4,381$ \\
\hline (In percent of GDP) 4/ & -0.5 & -3.3 & -2.8 & -1.3 & -2.6 & -4.0 & -4.2 & -4.8 & -5.1 & -5.3 & -5.5 \\
\hline Grants & 42 & 60 & 85 & 64 & 33 & 110 & 148 & 168 & 188 & 208 & 228 \\
\hline Capital account & 644 & 372 & 1,098 & 2,673 & 1,397 & 3,133 & 2,906 & 3,281 & 3,968 & 4,416 & 4,932 \\
\hline Of which: FDI & 715 & 976 & 963 & 969 & 1,992 & 2,325 & 1,811 & 2,050 & 2,600 & 3,000 & 3,350 \\
\hline Errors and omissions & -348 & 202 & -220 & $-2,480$ & -620 & 0 & 0 & 0 & 0 & 0 & 0 \\
\hline \multirow[t]{2}{*}{ Overall balance } & 239 & -405 & -28 & -333 & -522 & 1,124 & 626 & 437 & 738 & 746 & 779 \\
\hline & \multicolumn{11}{|c|}{ (In millions of U.S. dollars, unless otherwise indicated) } \\
\hline \multicolumn{12}{|l|}{ External debt and reserves } \\
\hline Total external debt (including arrears) & 12,305 & 12,744 & 13,207 & 13,643 & 14,632 & 12,251 & 11,230 & 12,666 & 14,190 & 15,713 & 17,401 \\
\hline (In percent of GDP) 4/ & 61.0 & 40.6 & 37.5 & 30.1 & 28.4 & 23.1 & 19.6 & 20.4 & 21.0 & 21.4 & 21.8 \\
\hline External debt arrears 5/ & 8,365 & 8,825 & 9,323 & 9,850 & 10,592 & 2,372 & 0 & 0 & 0 & 0 & 0 \\
\hline Gross official reserves & 2,039 & 2,254 & 2,909 & 3,309 & 3,818 & 5,071 & 5,697 & 6,134 & 6,871 & 7,617 & 8,397 \\
\hline (In months of total imports) & 3.2 & 3.5 & 3.8 & 3.5 & 3.3 & 4.0 & 3.9 & 3.8 & 3.8 & 3.6 & 3.5 \\
\hline Exhange rate (period average, kyat/U.S. dollar) & 1156 & 917 & 918 & 803 & 772 & $\ldots$ & $\ldots$ & $\ldots$ & $\ldots$ & $\ldots$ & $\ldots$ \\
\hline Exhange rate (percent change) & -0.5 & -20.7 & 0.1 & -12.6 & -3.8 & $\ldots$ & $\ldots$ & $\ldots$ & $\ldots$ & $\ldots$ & $\ldots$ \\
\hline \multicolumn{12}{|c|}{$\begin{array}{l}\text { 1/ The authorities plan to adopt a managed float in FY2012/13. } \\
\text { 2/ Including livestock, fishery, and forestry. } \\
3 \text { / Including manufacturing, power, energy, construction, and mining. } \\
\text { 4/ Before FY2012/13, GDP converted at a weighted exchange rate, where the official and FEC market rates are weighted about } 8 \text { and } 92 \text { percent, } \\
\text { based on the public and private sectors' respective shares in GDP. } \\
\text { 5/ For 2012/13 and onwards incorporate the terms of bilateral arrears clearance agreement with Japan. }\end{array}$} \\
\hline
\end{tabular}




\section{APPENDIX I. MYANMAR-LETTER OF INTENT}

Nay Pyi Taw, December 28, 2012

Ms. Christine Lagarde

Managing Director

International Monetary Fund

Washington, D.C. 20431

Dear Ms. Lagarde,

Myanmar is in the midst of a historic transition. After substantial progress in the first stage of reforms, which aimed at achieving peace and national unity, the new government of Myanmar has embarked on second-stage reforms targeting an immediate improvement of the economic and social well-being of Myanmar's citizens. To realize our economy's rich potential and reduce poverty in a sustainable manner, our government aims to comprehensively modernize the economy and integrate it with the global economy, including through regularization of financial relations with the international community. We recognize that to successfully meet these challenges, lasting macroeconomic stability is critical.

Therefore, our government has developed a program of economic policies and institutional reforms for the period through December 2013, which is outlined in the attached Memorandum of Economic and Financial Policies (MEFP). Our program is intended at laying the foundations for continued macroeconomic stability by further building capacity for macroeconomic management, and establishing a track record of sound macroeconomic policies. We request IMF staff to assist us in monitoring the implementation of this program via a joint assessment next year-called a twelve-month staff-monitored program (SMP) by the IMF-so as to pave the way for a potential formal Fund arrangement. This would support our broader reform efforts, which are being undertaken with the assistance of the World Bank, the Asian Development Bank, and bilateral donors.

We believe that the policies set forth in the attached MEFP are adequate to achieve our program's goals. However, if needed, our government stands ready to take any additional measures that may become necessary to achieve them. We will continue to consult closely with IMF staff, including on the adoption of such measures, and in advance of any revision to the policies outlined in the MEFP. We will also provide IMF staff with the information necessary to monitor the implementation of our program. 
Our government authorizes the IMF to publish the staff report, this Letter of Intent, and the attached Memorandum of Economic and Financial Policies and Technical Memorandum of Understanding.

Sincerely yours,

/s/

U Win Shein

Union Minister of Finance and Revenue /s/

U Than Nyein

Governor, Central Bank of Myanmar 


\section{ATTACHMENT I. MYANMAR: MEMORANDUM OF ECONOMIC AND FINANCIAL POLICIES}

\section{Introduction}

1. Myanmar is in the midst of a historic political and economic transition. After decades of isolation and conflict, the new government of Myanmar, which came to power following the elections in 2010, has embarked on a comprehensive program of political and economic reforms with the aims of becoming a modern developed nation that meets the aspirations of its people for a better life, and better integrating Myanmar with the international community. These objectives are closely linked and mutually reinforcing. In the first stage of these reforms, we took far-reaching steps toward national reconciliation with political parties and nationality groups. Recently, our government has laid the groundwork for second-stage reforms aimed at improving the economic and social well-being of Myanmar's citizens.

\section{We have outlined our government's overarching goals in the draft Framework for} Economic and Social Reforms (FESR). Myanmar is a low-income country (LIC) in Southeast Asia, with a poverty headcount of 26 percent in 2010, largely concentrated in rural areas. While some progress toward achieving the Millennium Development Goals (MDGs) has been made, Myanmar lags other countries in the region on most indicators. The government is paying the highest attention to poverty alleviation and to reaching the MDGs. To this end, the FESR is aimed at helping achieve sustained economic growth and poverty reduction with the goal of graduation from LIC status, which in turn will facilitate further progress in the national reconciliation and democratization process currently underway. To achieve our national goals outlined in the FESR, we have identified as policy priorities (i) sustained industrial and agricultural development to attain poverty alleviation and rural development; (ii) equitable sharing of resources among regions and states while promoting local and foreign investment; and (iii) effective implementation of people-centered development, through community-driven, participatory approaches to improve education, health, and overall living standards. Full economic integration with ASEAN in accordance with the ASEAN Economic Community schedule will reinforce these policies. Key measures to implement our policies are land reform to reduce landlessness, improving access to credit, and supporting access to both domestic and overseas job markets, as well as industrial development to provide job opportunities.

\section{Our Program Objectives and Policies}

3. We recognize that, to achieve our broader goals, ensuring macroeconomic stability during the reform process is critical. Our program aims to (i) maintain macroeconomic stability and ensure debt sustainability; and (ii) lay the foundations for lasting macroeconomic stability by building a macroeconomic framework, and develop the institutions and instruments to use it 
effectively. Our macroeconomic goals are to maintain stable and low inflation and increase our international reserves to provide a buffer against external shocks during the reform process. We have already begun implementing reforms in related policy areas:

- $\quad$ Foreign exchange regime. We replaced the peg to the SDR (at 8.51 kyat/SDR) with a managed float on April $2^{\text {nd }}, 2012$, where the reference exchange rate is determined in an auction mechanism; lifted key exchange restrictions (including the requirement to use only export proceeds for imports); and issued licenses to conduct international banking to a number of private banks. As a consequence, the difference between the reference rate and the informal market rate has diminished significantly. We also eliminated the discretionary authorization by the Central Bank of Myanmar (CBM) that allows market participants to quote at times exchange rates outside the $+/-0.8$ percent band (including by more than two percent). In addition, we have aligned the maximum spread around the reference exchange rate that banks are allowed to quote customers with that at retail counters to encourage further flows into the formal market. A new foreign exchange management law targeting to lift all restrictions on current payments and transfers was passed by the parliament in August, though implementing regulations still need to be drafted.

Financial sector reform. We liberalized the bank deposit rates within a fixed corridor, expanded eligible collateral to include key agricultural export goods, lifted additional capital requirements for branch expansion, and eliminated the deposit-to-capital ratio requirement. We also licensed four new commercial banks.

Central bank reform. A central bank law has been approved by the cabinet and awaits passage by parliament. It aims to provide more operational autonomy and proper accountability to the CBM and equipping it with core central banking functions, some of which are currently undertaken by state banks. We have formed a committee which has identified the stock of official foreign exchange reserves at state banks and have begun their gradual transfer to the CBM.

- Monetary policy framework. The CBM is making preparations to adopt a reserve money targeting framework. Pending the development of a secondary treasury securities market, monetary policy implementation will primarily be conducted via open market operations in the form of deposit and credit auctions, which have recently begun.

Fiscal sector. Our goals in the near term are to increase transparency and accountability in the budget process, allocate more spending to reaching our development goals, and lay the basis for higher revenue collections in the medium term. In line with those objectives, the FY2012/13 budget was, for the first time, debated in and approved by the Parliament. It increases allocations for health and education almost fivefold and twofold, respectively, compared to FY2011/12, financed to a significant extent by the positive revenue impact of adopting a more realistic market-based exchange rate in state economic enterprise 
(SEE) operations. We have also increased civil servant pensions from very low levels. At the same time, in a first step to increase their financial autonomy, SEEs have been granted limited autonomy to finance part of their operating costs by themselves (instead of through direct budget allocations). We abolished the withholding tax on imports, simplified the commercial tax on domestic sales, broadened the tax base by requiring public sector employees to pay income tax, and steepened the progressivity of the income tax. We have also eliminated a tax on key agricultural exports to support external competitiveness.

4. As a result of these policies, economic performance has improved in FY2011/12 and the economic outlook is favorable. In FY 2011/12, growth accelerated slightly to 51/2 percent, while inflation (IMF estimate) declined rapidly to 5 percent $(y / y)$, from almost 9 percent $(y / y)$ the previous year, mainly due to declining food prices and lower deficit monetization. The fiscal deficit rose moderately, to 6 percent of GDP (IMF definition). While the current account deficit widened to $2 \frac{1}{2}$ percent of GDP, international reserves rose to $\$ 4.2$ billion at end-September, covering $3 \frac{1}{4}$ months of recorded prospective imports of goods and nonfactor services (GNFS). Growth in FY2012/13 is projected to accelerate to around 61/4 percent, supported by higher investment, while inflation would rise somewhat to about 6 percent $(y / y)$, largely due to the effect of rising international food prices. The balance of payments, despite a projected further increase in the current account deficit to 4 percent of GDP, is forecast to reach an overall surplus largely financed by FDI, raising reserve coverage of prospective GNFS imports to around 4 months. The budget deficit is projected to record about 51/4 percent of GDP (IMF definition) in FY2012/13, after budget revisions. We intend to continue to increase spending on health, education and infrastructure, afforded by higher natural gas revenues.

5. We are also making efforts to clear our arrears to official bilateral and multilateral creditors. We have already agreed with Japan to this end, and are in advanced discussions with the World Bank and Asian Development Bank (AsDB) to clear arrears to them, which we expect to pave the way for a resumption of assistance from these institutions. We have also accepted the invitation of the Paris Club to discuss options for clearance of arrears with its members.

\section{As we continue with our reforms, we have requested IMF staff to assist us in} monitoring our economic policies through December 2013. Our work with the Fund will focus on the following areas: (i) eliminating remaining exchange restrictions and multiple currency practices (MCPs); (ii) modernizing the financial sector, including the $\mathrm{CBM}$, to facilitate macroeconomic management and growth; and (iii) laying the foundations for improving our fiscal revenues in the medium term for sustainable development spending. In all of these areas, we are requesting continued IMF technical assistance (TA).

\section{A. Foreign Exchange Policies}

7. Our goal is to accept our obligations of Article VIII Section 2(a), 3 and 4 of the IMF's Articles of Agreement in 2013. We consider the reforms of the foreign exchange regime and 
lifting restrictions on current payments and transfers essential to improve the external competitiveness of our economy, increase trade, and bring us closer to our ASEAN integration goals. Consistent with this, we will eliminate remaining exchange restrictions and MCPs, and will seek approval of the IMF's Executive Board for the MCP arising from our multi-priced foreign exchange auctions which is nondiscriminatory and will be maintained on a temporary basis until the foreign exchange market of Myanmar develops. In addition, we will (i) remove the exchange restriction on invisibles by lifting the $\mathrm{CBM}$ approval requirement to make payments and transfers for these; and (ii) announce a plan to phase out Foreign Exchange Certificates (FECs) that will remove any legal requirement for their use and include a time table to redeem them (structural benchmarks). We will also coordinate closely with IMF staff to ensure that new legislation, regulations, and bilateral payment arrangements do not create new exchange restrictions, and provide them with the necessary information.

\section{We will take additional steps to deepen and facilitate the smooth functioning of} the formal foreign exchange markets. To enable private banks to offer foreign exchange operations and services at par with state banks, we will remove restrictions that currently prevent them from doing so (structural benchmark). In particular, we will allow them to open foreign exchange accounts for all private sector entities, embassies, and international and nongovernmental organizations; align the permissible frequency of foreign exchange cash withdrawals with that of state banks; and remove the requirement for the CBM's prior approval for transfers abroad by private banks.

\section{In conducting foreign exchange auctions, the CBM will strive to ensure further} convergence of the formal and informal market rates. To achieve this, the CBM will encourage faster adjustment of the reference rate in case of large deviations between the reference rate and the informal market rate, while at the same time supporting the liquidity of the foreign exchange market, including through increased interventions without targeting a specific exchange rate level.

\section{B. Monetary Policy and Financial Sector Modernization}

\section{Strengthening our capacity to conduct monetary policy is a critical prerequisite for} macroeconomic management. We will focus on enabling the CBM to assume core central banking functions and improve its capacity to conduct monetary policy. To this end, we will (i) pass a central bank law providing operational autonomy and accountability to the CBM and equipping it with foreign reserve management functions currently carried out by state banks by March 2013; and (ii) continue gradually transferring the stock of international reserves currently held by state banks to the CBM, with the aim of completing the full transfer in 2014.

11. We will also improve and make better use of our existing toolkit for more effective monetary policy implementation. The CBM will conduct its deposit and credit auctions regularly to offset its net foreign exchange operations, while it continues to develop its reserve money forecasting capacity with the aim of moving to a reserve money targeting framework by 
late-2013. In the meantime we will recalibrate our key monetary policy instruments in 2013 and in line with banks' capacity to comply, by including in the definition of banks' required reserves only current account balances with the CBM, lengthening the reserve maintenance period to two weeks, and adjusting the required reserve ratio and liquid asset ratio in line with previous IMF TA recommendations. These requirements will also be applied to state banks. In addition, we will remove any remaining restrictions on interbank trading.

\section{We intend to take steps to modernize our regulations and strengthen supervisory} capacity to support financial sector development. In particular, we will bring the definitions of bank capital and nonperforming loans closer to international standards; strengthen the enforcement of connected lending limits to contain risks to financial stability during the modernization process of the financial sector; and improve banks' risk management as a precursor to liberalization of lending rates and maturities. In addition, we aim to replace the mandatory surrender requirement of excess foreign exchange positions-which is applied to private banks only - with a net open position limit. These changes will be implemented step by step, in line with the development of needed supervisory capacity. To support their implementation, we have requested two resident advisors on bank regulation and supervision from the IMF.

\section{We view developing financial markets as essential to facilitating the financing of} the budget deficit without resort to monetization. As an initial step, we will allow the Myanma Economic Bank to buy treasury bonds to gradually eliminate its structural excess liquidity, reduce its losses and monetization. We will also prepare the necessary regulations to introduce auctions of treasury securities (structural benchmark).

\section{Fiscal Policies}

14. We will orient our fiscal policies toward supporting continued macroeconomic stability, while providing sufficient room for much-needed social and investment spending. Therefore, we aim to keep the fiscal deficit in FY2013/14 and over the medium-term broadly unchanged at around 5 percent of GDP (IMF definition, which corresponds to around 4 percent of GDP based on our definition), while further increasing allocations for investment and recurrent spending in the health and education sectors in line with the FESR, as well as infrastructure investment. Higher expenditures will be supported mainly by rising revenues from gas projects coming on stream. We will use nonconcessional external borrowing only to finance economically viable projects in priority sectors such as energy and infrastructure, at levels consistent with maintaining debt sustainability and low risk of debt distress.

\section{We will endeavor to improve our tax revenues to reduce dependence on natural} resource revenues in the medium term. This is a prerequisite to achieve our goal to boost development spending and investment on a sustainable basis to support poverty reduction and graduate from LIC status, while maintaining low public debt levels. Tax policy and administration reforms will be implemented gradually and in a coordinated manner. We are planning to develop 
strategic plans for both tax administration and tax policy with the broad aims to further simplify rates while broadening the tax base, promote environmental conservation, move toward greater reliance on indirect taxes and self-assessment in direct taxation, and improve the capacity of the tax administration. However, we will begin implementing initial reform steps in both areas. In tax administration, we will establish a large taxpayer office with the aim for it to become operational in September 2013 (structural benchmark). On tax policy, we are considering reforming the taxation of special consumption goods (such as alcohol, tobacco, luxury items, and polluting goods). This would lay the foundation for an eventual move to a value added tax, which would encompass equalizing commercial tax rates for all goods. We will also streamline tax incentives for investment in the income tax law.

16. We will also take steps to improve public financial management. We will establish a treasury and debt management function in the Ministry of Finance and Revenue during 2013, as recommended by recent IMF and World Bank TA. Detailed plans for achieving these will be developed in the context of continuing TA from the IMF and World Bank. We will also conduct a public expenditure review with the help of the Word Bank to better inform our fiscal policies and improve efficiency of public spending in our priority areas.

\section{Reforms for Achieving Sustainable and Equitable Growth}

17. In the medium term Myanmar's economic prospects are good. Our country has rich natural resources, a young labor force and could benefit significantly from its strategic location in a dynamic region. While these conditions would support our aim for higher growth in the medium term, we recognize that further reforms would be needed to realize this potential. We project GDP growth to increase to around 7 percent over the medium term, supported by rising investment, both domestic and foreign. Inflation is expected to remain moderate at around 5 percent. We aim to further build international reserves to provide a cushion against possible adverse shocks that may arise from external developments beyond our control, as well as macroeconomic risks arising from the reform process itself.

\section{Realizing the potential of our economy will require increased local and foreign} investment, and major advances in health and education. A foreign investment law to ensure a stable and predictable environment for external investors has been passed by Parliament, and we are drafting an overhaul of the law on special economic zones, which are key to supporting industrialization. A comprehensive investment climate assessment is planned by the World Bank to guide broader reforms for private sector development. To support agricultural development, new land laws giving titles to farmers and encouraging the development of fallow land for agricultural use, and a new microfinance law to improve access to finance, were passed by the Parliament. To improve health and education of our citizens, we plan increased spending on related infrastructure, as well as broader sector-wide reforms. We are also focusing on developing key infrastructure, including energy, transport, and telecommunications. Sectoral 
plans for these critical areas are currently being prepared, with the support of the World Bank and AsDB.

\section{E. Statistics}

19. Reliable statistics are critical for informed public policy decisions. We are placing high priority on improving the accuracy and timeliness of our statistics. To this end, we have already received, and have requested further TA from the IMF and other development partners.

\section{F. Program Monitoring}

20. We intend to closely monitor the implementation of our program. To this end, we have established a number of quantitative and structural benchmarks for end-March 2013 and end-September 2013, listed in Tables 1 and 2, respectively. These benchmarks will form the basis for assessments scheduled for June 2013 and January 2014. We will also put in place a framework for monitoring by creating a committee including representatives from the CBM, MOFR and the Ministry of National Planning and Economic Development to report to the Minister of Finance and Revenue. Based on these reports, the Minister will regularly brief the cabinet on progress with our reform program. The definitions of the relevant variables are contained in the Technical Memorandum of Understanding (Attachment II). 
Table 1. Myanmar: Indicative Quantitative Benchmarks 1/

\begin{tabular}{|c|c|c|c|c|c|c|c|}
\hline \multirow[b]{3}{*}{$\begin{array}{l}\text { Net international reserves of the CBM 2/ 3/ } \\
\text { (cumulative flow from end-Sept 2012; in millions of US\$) }\end{array}$} & \multicolumn{7}{|c|}{$\underline{\text { Sep } 2012} \underline{\text { Dec } 2012} \underline{\text { Mar } 2013} \underline{\text { Jun } 2013} \underline{\text { Sep } 2013} \underline{\text { Dec } 2013}$ Mar 201} \\
\hline & Est. & Proj. & Target & Proj. & Target & Proj. & Proj. \\
\hline & .. & 655 & 705 & 1,300 & 1,504 & 1,916 & 2,125 \\
\hline $\begin{array}{l}\text { Net domestic financing of the NFPS deficit } 4 \text { / } \\
\text { (cumulative flow from the beginning of the fiscal year to end-period; in billions of kyat) }\end{array}$ & 369 & 1,533 & 1,921 & 343 & 1,053 & 1,523 & 1,815 \\
\hline $\begin{array}{l}\text { Net CBM financing of the NFPS deficit 4/ } \\
\text { (cumulative flow from the beginning of the fiscal year to end-period; in billions of kyat) }\end{array}$ & 228 & 376 & 960 & 31 & 191 & 314 & 794 \\
\hline $\begin{array}{l}\text { Accumulation of new external payment arrears by the non-financial public sector } 5 \text { / } \\
\text { (ceiling on stock at end-period; in millions of US\$) }\end{array}$ & 0 & 0 & $\mathbf{0}$ & 0 & 0 & 0 & 0 \\
\hline $\begin{array}{l}\text { Contacting or guaranteeing of nonconcessional external debt } \\
\text { (ceiling; in millions of US\$) }\end{array}$ & $\ldots$ & $\ldots$ & 2,000 & 2,000 & 2,000 & 2,000 & 2,000 \\
\hline $\begin{array}{l}\text { 1/ Fiscal year begins April } 1 . \\
\text { 2/ Includes SDR and Gold. Valued at program exchange rate of Euro/USD }=1.27 \text { and a gold } \\
3 \text { / Assumes transfer of international reserves from state banks to the CBM of US } \$ 762 \mathrm{mn} \text { b } \\
\text { 4/ The nonfinancial public sector (NFPS) comprises the Union government and state econo } \\
\text { 5/ Excludes accumulation of new arrears on debt already in arrears. }\end{array}$ & $\begin{array}{l}\text { d price of U } \\
\text { by end-Ma } \\
\text { omic enterp }\end{array}$ & $\begin{array}{l}, 750 p \\
2013, \\
\text { es. A p }\end{array}$ & $\begin{array}{l}\text { troy ou } \\
\text { d a furtl } \\
\text { gram ex }\end{array}$ & $\begin{array}{l}\text { US\$68 } \\
\text { inge ra }\end{array}$ & $\begin{array}{l}\text { nn by en } \\
\text { of } 850 k\end{array}$ & $\begin{array}{l}\text { eptem } \\
\text { per US }\end{array}$ & $\begin{array}{l}2013 . \\
\text { oplies. }\end{array}$ \\
\hline
\end{tabular}

Table 2. Myanmar: Structural Benchmarks

\begin{tabular}{|c|c|c|}
\hline Actions & Date & Macroeconomic Obiective \\
\hline $\begin{array}{l}\text { Eliminate exchange restrictions on payments and transfers for } \\
\text { invisibles (MEFP } \llbracket 7 \text { ) }\end{array}$ & March 2013 & To eliminate Article VIII restrictions \\
\hline $\begin{array}{l}\text { Announce a plan for phasing out Foreign Exchange Certificates } \\
\text { (MEFP आ7) }\end{array}$ & March 2013 & $\begin{array}{l}\text { To eliminate a multiple currency } \\
\text { practice }\end{array}$ \\
\hline $\begin{array}{l}\text { Remove restrictions that prevent private banks from conducting } \\
\text { foreign exchange operations at par with state banks (MEFP ฯ8) }\end{array}$ & March 2013 & To help unify informal exchange rates \\
\hline $\begin{array}{l}\text { Prepare regulations to introduce treasury securities auctions } \\
\text { (MEFPף13) }\end{array}$ & $\begin{array}{l}\text { September } \\
2013\end{array}$ & $\begin{array}{l}\text { To facilitate market-based deficit } \\
\text { financing }\end{array}$ \\
\hline Establish an operational large taxpayer unit (MEFPף15) & $\begin{array}{l}\text { September } \\
2013\end{array}$ & $\begin{array}{l}\text { To improve tax administration and } \\
\text { increase tax revenues }\end{array}$ \\
\hline
\end{tabular}




\section{ATTACHMENT II. MYANMAR: TECHNICAL MEMORANDUM OF UNDERSTANDING}

1. This memorandum describes the definitions of the quantitative indicators for the staffmonitored program (SMP), as well as the respective reporting requirements.

\section{Indicative Quantitative Targets and Definitions}

2. Indicative quantitative targets have been set for end-March 2013, and for end-September 2013 with respect to net international reserves of the Central Bank of Myanmar (CBM), net domestic financing of the nonfinancial public sector (NFPS) deficit, net CBM financing of the NFPS deficit, accumulation of new external payments arrears by the NFPS, and contracting or guaranteeing of nonconcessional external debt, as specified in Table 1 of the Memorandum of Economic and Financial Policies (MEFP).

3. The NFPS comprises the Union government and state economic enterprises (SEEs).

4. Program exchange rates and the program gold price, as specified in Table 1 of the MEFP, will be used to convert foreign currency cash and accounts into U.S. dollars, U.S. dollar cash and accounts into kyat, and value gold holdings. Cash and accounts in currencies other than those mentioned above will be converted at the actual exchange rates at end-period as published in the International Financial Statistics.

\section{A. Net International Reserves of the CBM}

5. A floor applies to net international reserves of the CBM, measured cumulatively from end-September 2012.

6. Net international reserves are calculated as the difference between gross international reserve assets and international reserve liabilities and foreign currency deposits at the CBM, valued at the program exchange rates and gold price.

7. Gross international reserve assets of the CBM are defined as the sum of monetary gold holdings of the CBM; holdings of SDRs; Myanmar's reserve position in the IMF; cash in foreign currencies; and foreign currency assets held abroad that are under the direct and effective control of the CBM.

8. International reserve liabilities of the $\mathrm{CBM}$ are defined as foreign currency liabilities of the CBM to nonresidents with an original maturity of up to and including one year, excluding SDR allocations. 
9. Foreign currency deposits at the CBM include foreign currency and Foreign Exchange Certificate (FEC) deposits of commercial banks including state banks, SEEs, and the government held with the CBM.

\section{B. Net Domestic Financing of the NFPS Deficit}

10. A ceiling applies to the net domestic financing of the NFPS deficit, measured cumulatively from the beginning of the fiscal year (April 1). Net domestic financing is defined as the sum of (i) net domestic bank financing and (ii) net domestic nonbank financing.

11. Net domestic bank financing is defined as the sum of (i) the change in net CBM credit to the NPFS, and (ii) the change in state and non-state commercial banks' claims on the central government in domestic and foreign currency, including the change in the holdings of government securities by banks, minus the balances of the NFPS held in commercial banks.

12. Net nonbank domestic financing is defined as the change in the holdings of government securities by the nonbank sector, calculated as the difference between the change in the stock outstanding of government securities and the change in the holdings of government securities by the banking system.

\section{Net CBM Financing of the NFPS Deficit}

13. A ceiling applies to the financing by the CBM of the NFPS deficit, measured cumulatively from the beginning of the fiscal year (April 1). Net CBM financing is defined as the change in net CBM credit to the NFPS.

\section{Nonconcessional External Debt}

14. A ceiling applies to the contracting or guaranteeing by the NFPS or the CBM of new nonconcessional debt of any maturity with nonresidents denominated in foreign currency, measured cumulatively from the start of the SMP, and applies continuously. The ceiling applies to the total amounts of debt and commitments contracted or guaranteed, regardless of when disbursements are made.

15. The definition of debt, for the purposes of the SMP, is set out in Point No. 9 of the Guidelines on Performance Criteria with Respect to Foreign Debt (Executive Board Decision No. 6230-(79/140), last amended by Executive Board Decision No. 14416-(09/91), adopted August 31, 2009). A debt is concessional if it includes a grant element of at least 35 percent, using the currency-specific commercial interest reference rate. ${ }^{1}$

\footnotetext{
${ }^{1}$ A more detailed discussion of the concessionality concept and a calculator to estimate the grant elements of a financing package are available at the IMF website at: http://www.imf.org/external/np/pdr/conc/index.htm.
} 
16. For program purposes, the guarantee of a debt arises from any explicit legal obligation of the NFPS or the CBM to service a loan in the event of nonpayment by the recipient (involving payments in cash or in kind), or indirectly through any other obligation of the NFPS or the CBM to finance a shortfall incurred by a loan recipient.

17. Excluded from the ceiling are (i) use of IMF credit; (ii) debts to the World Bank and Asian Development Bank; (iii) debts incurred to refinance or prepay existing debts, to the extent that such debt is incurred on more favorable terms than the existing debt; (iv) debts incurred to restructure existing debt or arrears; ( $v$ ) debts classified as international reserve liabilities by the $\mathrm{CBM}$; and (vi) import financing to SEEs.

18. The government will inform Fund staff in a timely manner before contracting any debt of this type and will provide sufficient information ahead of time to verify the degree of concessionality. It will also provide a brief summary of the projects to be financed, including an evaluation by the lender or the government, if available.

\section{E. External Payment Arrears}

19. A continuous benchmark applies to the non-accumulation of external payment arrears on external debt contracted or guaranteed by the NFPS or the CBM. The accumulation of new external payment arrears on debt already in arrears is excluded from this definition. Also excluded from this definition are arrears accumulated on debt subject to cancellation, rescheduling or restructuring. External payment arrears consist of external debt service obligations (principal and interest) that have not been paid at the time they are due, as specified in the contractual agreements.

\section{Data Provision}

20. The authorities will provide to the IMF's Asia and Pacific Department the data required to monitor performance under the SMP. All data revisions will be promptly reported. The data to be reported and reporting responsibilities are listed below.

\section{Monetary data are reported by the CBM.}

- The monetary survey, the CBM's balance sheet, and the consolidated balance sheet of commercial banks will be reported on a monthly basis within 3 months of the end of the respective month.

- $\quad$ Any change in interest rates of CBM facilities will be reported within five working days.

\section{Fiscal data are reported by the CBM and the Ministry of Finance and Revenue} (MOFR). 
- Data on the net credit to the central government, nonfinancial public enterprises, and state and local governments by the CBM and by commercial banks will be reported within 3 months from the end of the respective month by the CBM.

- Data on the outstanding total stock of government securities as well as the stock outstanding to the CBM and to deposit money banks (DMBs), broken down by treasury bills and treasury bonds, will be reported on a monthly basis within 3 months from the end of the respective month by the CBM.

\section{External sector data are reported by the CBM and the MOFR.}

- International reserves held by the CBM, broken down by currency and instruments held at the end of the month will be reported on a monthly basis within two weeks of the end of the respective month.

- Foreign liabilities and foreign-currency deposits of the CBM, broken down by creditor, currency, maturity and instruments held at the end of the month will be reported on a monthly basis within two weeks of the end of the respective month.

Foreign assets held by state banks broken down by ultimate owner of the assets (government, SEEs, or other), currency and instruments held at the end of the month will be reported on a monthly basis within two weeks of the end of the respective month.

Outstanding stock, disbursements, amortization, and interest payments of short-term (with maturities of one year or less) and medium- and long-term (with maturities of more than one year) external debt contracted or guaranteed by the government, SEEs, or the CBM by creditor in original currency and U.S. dollars on a quarterly basis, to be provided within 8 weeks of the end of the respective quarter.

- External debt newly contracted or guaranteed by the government, SEEs, or the CBM, including terms (interest rate and grace and repayment periods) on a quarterly basis, to be provided within 8 weeks of the end of the respective quarter.

Arrears on the external debt contracted or guaranteed by government, SEEs, or the CBM by creditor in original currency and U.S. dollars on a quarterly basis, to be provided within 8 weeks of the end of the respective quarter. basis, to be provided within 8 weeks of the end of the respective quarter. 